\title{
Algunas notas sobre Abraham Bienveniste, Rab Mayor de los judíos y tesorero real en tiempos de Juan II de Castilla*
}

\author{
Some Notes on Abraham Bienveniste, Chief Rabbi of the Jews \\ and Treasurer in Times of Juan II of Castile
}

\author{
EnRique Cantera Montenegro**
}

\begin{abstract}
RESUMEN
Este artículo se centra en el estudio de Abraham Bienveniste, una de las personalidades más destacadas del judaísmo castellano en la primera mitad del siglo XV, en su triple faceta de Rab Mayor

de los judíos de Castilla, tesorero real y arrendador de rentas de la Hacienda regia. A lo largo del trabajo, Abraham Bienveniste emerge como una figura destacada en el complejo entramado político castellano de los años veinte y treinta del siglo XV, y como una pieza clave pare comprender la evolución del judaísmo castellano en el período que media entre las persecuciones de 1391 y la expulsión de 1492.
\end{abstract}

\section{PALABRAS CLAVE}

Abraham Bienveniste, Juan II de Castilla, Álvaro de Luna, Rab Mayor de los judíos, siglo XV, tesorero real, Hacienda regia.

\begin{abstract}
This study focuses on Abraham Bienveniste, one of the most prominent Jewish figures in Castile in the first half of the fifteenth century in his triple role as Chief Rabbi of the Castilian Jews, royal treasurer, and tax farmer of the royal fisc. Throughout this study, Abraham Bienveniste emerges as a central figure in the complex political framework of Castile in the twenties and thirties of the fifteenth century, and is a fundamental part of the history of Castilian Judaism in the period between the 1391 persecutions and the expulsion of 1492.
\end{abstract}

\section{KEY WORDS}

Abraham Bienveniste, Juan II of Castile, Álvaro de Luna, Chief Rabbi of the Jews, Fifteenth Century, Royal treasurer, Royal fisc.

* Fecha de recepción del artículo: 2013-12-11. Fecha de aceptación del artículo: 2014-1-9.

Este trabajo se realiza en el marco del Proyecto de Investigación titulado El ejercicio del poder en Castilla en la primera mitad del siglo XV, financiado por el Ministerio de Ciencia e Innovación (Referencia: HAR2009-09912 - Subprograma HIST).

** Departamento de Historia Medieval y Ciencias y Técnicas Historiográficas. UNED. C.e.: ecantera@ geo.uned.es 


\section{APROXIMACIÓN BIOGRÁFICA A ABRAHAM BIENVENISTE Y REFLEJO DE SU PERSONALIDAD EN LAS CRÓNICAS CASTELLANAS E HISPANOHEBREAS}

Abraham Bienveniste es uno de los representantes más destacados del judaísmo castellano de la primera mitad del siglo XV, lo que no obsta para que sean muy pocos los datos ciertos que conocemos acerca de su trayectoria vital. Algunos autores fijan sus orígenes en la ciudad de Soria en los primeros años del siglo $\mathrm{XV}^{1}$, en tanto que otros lo consideran oriundo de Burgos $^{2}$ o ponen de relieve su condición de vecino de Guadalajara ${ }^{3}$. La familia de los Bienveniste constituye uno de los linajes judíos más importantes en Castilla y Aragón a lo largo de la Baja Edad Media, con diversas ramas establecidas, principalmente, en las ciudades de Burgos ${ }^{4}$,

1 Entre otros autores, SÁENZ BADILLOS, Ángel, y TARGARONA BORRÁS, Judit, Diccionario de autores judíos (Sefarad. Siglos X-XV). Córdoba. Ediciones El Almendro, 1988, pág. 5, BEINART, Haim, Los judíos en España. Madrid. Mapfre, 1992, pág. 180, y VALDEÓN BARUQUE, Julio, Judíos y conversos en la Castilla medieval. Valladolid. Universidad de Valladolid-Ámbito, 2000, pág. 91, hacen referencia a Abraham Bienveniste como judío soriano.

2 SUÁREZ FERNÁNDEZ, Luis, “Los infantes de Aragón y Don Álvaro de Luna (1416-30)», capítulo IV de Los Trastámaras de Castilla y Aragón en el siglo XV. Juan II y Enrique IV de Castilla (1407-1474). El Compromiso de Caspe, Fernando I, Alfonso V y Juan II de Aragón (1410-1479), por Luis Suárez Fernández, Ángel Canellas López y Jaime Vicens Vives, en Historia de España dirigida por Ramón Menéndez Pidal, tomo XV. Madrid. Espasa Calpe, 1982 (3. a ed.), pág. 101.

3 ORTEGO RICO, Pablo, Hacienda, poder real y sociedad en Toledo y su Reino (siglo XV-principios del XVI). Tesis doctoral inédita. Madrid. Universidad Complutense de Madrid, 2013, 2 vols. (en concreto, vol. II, pág. 871).

${ }_{4}^{4}$ La rama burgalesa de los Bienveniste tuvo una destacada intervención en la vida de la ciudad de Burgos al menos desde mediados del siglo XIV, pudiendo estar emparentada con otra de las más prestigiosas familias judías de esta ciudad, la de los Levi (CANTERA BURGOS, Francisco, Alvar García de Santa María. Historia de la judería de Burgos y de sus conversos más egregios. Madrid, 1952, pág. 54, nota 48; hay una reimpresión de esta obra, en edición de Yolanda Moreno Koch y M. a Fuencisla García Casar, en Miranda de Ebro, Fundación Cultural «Profesor Cantera Burgos», 2007). A partir de los decenios centrales del siglo XIV hay referencias en la documentación a diversos miembros de la familia de los Bienveniste, y en 1391 aparece citado un Abraham Bienveniste como representante de la comunidad judía burgalesa; así queda constatado a través del más antiguo libro de actas del concejo burgalés que se ha conservado, conocido como «Libro de los fechos del Concejo», cuyas primeras noticias corresponden al año 1379. Entre los diversos acuerdos adoptados en septiembre de 1391 con motivo de la reunión de Cortes que iba a tener lugar en esta ciudad con el fin de tratar de solucionar la crisis que la minoridad de Enrique III había abierto por los enfrentamientos entre las distintas facciones políticas, se contiene una provisión para que acudiesen al ayuntamiento que iba a celebrarse el día 8 de ese mes Rabí Osua (Yehosua), don Yuçe (Yuçaf) Abenrresque, don Abraham Bienveniste y otros judíos, a quienes se ordenó que «çerrasen e tapiasen las puertas... que salen fuera de la judería». Las instrucciones dadas a los representantes de la aljama burgalesa se enmarcan en las numerosas medidas adoptadas por las autoridades concejiles con el fin de garantizar la seguridad de los asistentes a la sesión de Cortes. En la misma línea, los representantes de los judíos fueron obligados a jurar ante dos alcaldes «segunt su ley, en la Torá de Yzra, de no dar, nin vender, nin prestar, nin trocar armas» a cuantos acudiesen a las Cortes (Anselmo SALVÁ, Las Cortes de 1392 en Burgos. Burgos, 1891; CANTERA BURGOS, Francisco, Alvar García de Santa María. Historia de la judería de Burgos y de sus conversos más egregios, págs. 22-23, y «La judería de Burgos", en Sefarad, XII (1952), págs. 59-104 (véase pág. 77); SUÁREZ FERNÁNDEZ, Luis, La expulsión de los judíos de España. Madrid. Mapfre, 1991, pág. 192; y MITRE FERNÁNDEZ, Emilio, Los judíos de Castilla en tiempo de Enrique III. El pogrom de 1391. Valladolid. Universidad de Valladolid, 1994, pág. 22).

También en los últimos decenios del siglo XV la comunidad judía de Burgos contaba entre sus miembros con algunos que llevaban el apellido Bienveniste, como Salomón (Selomoh) y Abraham Bienveniste (SUÁREZ BILBAO, Fernando, Las ciudades castellanas y sus juderías en el siglo XV. Madrid. Caja de Madrid, 1995, págs. 80-81). 
Soria $^{5}$, Guadalajara ${ }^{6}$ y Zaragoza ${ }^{7}$. En cualquier caso, diversas referencias documentales parecen dejar suficientemente claro que Abraham Bienveniste tenía sus raíces en la ciudad de Soria. Así, en un documento con fecha de 11 de agosto de 1420, dado en Ávila, en el que el rey Juan II comunicaba al concejo de Murcia los movimientos que habían tenido lugar en la corte con ocasión del golpe de Tordesillas de julio de 1420, acontecimiento éste al que luego se hará referencia más detallada, se hace referencia a «un jodío de Soria que dizen Abrahem Benveniste ${ }^{8}$. Del mismo modo, en diversos documentos que se conservan en el Archivo Municipal de Burgos, correspondientes a los años 1428 a 1435, se hace mención a don Abraham Bienveniste de Soria como tesorero de las albaquías ${ }^{9}$, con lo que no hay duda de que se está refiriendo a nuestro Abraham Bienveniste, ya que por esas fechas, como se indicará más adelante, era tesorero de las «debdas, alcances e albaquías». Estos documentos fueron otorgados con ocasión de la ejecución de bienes a que fue condenado en 1428 Pedro Suárez, hermano del obispo de Burgos don Pablo de Santa María, como consecuencia de un alcance

${ }^{5}$ En la ciudad de Soria consta la presencia de la familia Bienveniste al menos desde el siglo XIV. Todo parece indicar que los Bienveniste sorianos tenían intereses en la ciudad de Burgos, y que mantenían unas fluidas relaciones con las familias judías burgalesas de los Bienveniste y los Levi. En 1413, Yuçaf Bienveniste el Mayor, vecino de Soria, vendió a Alvar García de Santa María unas casas situadas en la calle mayor de la Villa Nueva de Burgos, que antes habían pertenecido al judío burgalés don Çag (Yishaq) el Levi y luego al contador Juan Hurtado de Mendoza (CANTERA BURGOS, Francisco, «La judería de Burgos", pág. 85, y Alvar García de Santa María. Historia de la judería de Burgos y de sus conversos más egregios, pág. 54, nota 48). En los últimos decenios del siglo XV están documentados varios representantes destacados de la familia Bienveniste, entre ellos Abraham Bienveniste, hijo de Yuçaf Bienveniste y nieto de Abraham Bienveniste, que había sido circuncidado en 1433, y que figura como arrendador y recaudador de las alcabalas y tercias de Segovia (Archivo General de Simancas -AGS, Registro General del Sello- RGS, fol. 68, documento de 15 de abril de 1485) y de las alcabalas y tercias del obispado de Osma (AGS, RGS, fol. 59, documento de 28 de marzo de 1485). Una información más completa sobre los Bienveniste sorianos puede encontrarse en el trabajo de DIAGO HERNANDO, Máximo, «Judíos y judeoconversos en Soria en el siglo XV», en Celtiberia, XLIII, n. 84 (julio-diciembre de 1992), págs. 225-253.

${ }^{6}$ La familia Bienveniste ocupó un destacado lugar en la comunidad judía de Guadalajara al menos desde los primeros decenios del siglo XV. En los años setenta de esta centuria está documentado un Abraham Bienveniste, que fue arrendador y recaudador de la renta del servicio y montazgo de la Mesta en 1477, en compañía de Abraham Seneor (AGS, RGS, fol. 72, documento de 10 de octubre de 1477; AGS, RGS, fol. 118, documento de 19 de octubre de 1477; AGS, RGS, fol. 467, documento de 14 de diciembre de 1477; AGS, RGS, fol. 49, documento de 17 de marzo de 1478), y que en 1479 recibió autorización para construir un molino en el río Henares (AGS, RGS, fol. 22, documento de 23 de diciembre de 1479). Para una mayor información sobre los Bienveniste de Guadalajara puede consultarse el libro de VIÑUALES FERREIRO, Gonzalo, La Edad Media en Guadalajara y su provincia: los judíos. Guadalajara. Diputación de Guadalajara, 2003.

7 En Zaragoza consta la presencia al menos desde los últimos decenios del siglo XIV de algunos representantes de las distintas ramas castellanas de los Bienveniste, que en algún caso emparentaron con la poderosa familia de los Cavallería (CANTERA BURGOS, Francisco, Alvar García de Santa María. Historia de la judería de Burgos y de sus conversos más egregios, pág. 54, nota 48).

${ }^{8}$ Archivo Municipal de Murcia, Cartulario Real, 1411-1429, fol.s 105r-v. Documento transcrito en Colección de documentos para la historia del Reino de Murcia. XVI. Documentos de Juan II. Edición de Juan Abellán Pérez. Murcia-Cádiz. Academia Alfonso X el Sabio-Universidad de Cádiz-CSIC, 1984, págs. 81-85 (en concreto, véase doc. 37, pág. 82).

9 CANTERA BURGOS, Francisco, Alvar García de Santa María. Historia de la judería de Burgos y de sus conversos más egregios, págs. 105-108. 
por cuantía de 1.280 .000 maravedíes que le eran reclamados por Abraham Bienveniste, en su condición de tesorero real de las albaquías, del tiempo en que Pedro Suárez había tenido arrendadas diversas rentas situadas en tierras de los obispados de Cartagena y Segovia, así como el servicio y montazgo, en tiempos de Enrique III y de Juan II.

Otro dato que apoya el origen soriano de Abraham Bienveniste es que, según refiere Abraham Zacut en su Sefer Yuhasin ${ }^{10}$, en 1433 fue circuncidado en el castillo de Soria Abraham Bienveniste, hijo de Yuçaf Bienveniste y nieto de Abraham Bienveniste; en el acto religioso intervino con una homilía el afamado rabino y teólogo Rabí Yosef Albo ${ }^{11}$, quien por entonces residía en Soria ${ }^{12}$.

Es bien conocido que Abraham Bienveniste se vio inmiscuido en las luchas que se entablaron por el control político del reino de Castilla tras alcanzar el rey Juan II la mayoría de edad en marzo de 1419. Son precisamente estas discordias políticas, que se prolongarían en el reino de Castilla, con escasos períodos de paz, durante más de cincuenta años, las que posibilitaron a Abraham Bienveniste ganar una sólida posición en la corte castellana, de forma que su figura recuerda mucho a la de otros ilustres cortesanos judíos de las centurias precedentes ${ }^{13}$. En el año 1420 figuraba ya Abraham Bienveniste entre los oficiales de Juan Hurtado

10 Abraham Zacut, nacido en Alba de Tormes, sobresalió como astrónomo y astrólogo, y tuvo también grandes conocimientos de matemáticas, cábala, historia y ciencias jurídicas. En 1492 pasó a Portugal, donde permaneció hasta 1497; con motivo de la expulsión de los judíos de Portugal, se exilió, sucesivamente, en Túnez, Italia y Turquía, muriendo en Damasco alrededor del año 1515. El Sefer Yuhasin es una obra de contenido histórico que fue concluida en 1504, en Túnez. Su objetivo consiste en referir la transmisión de la ley oral y las generaciones de los maestros que se sucedieron hasta los tiempos de autor (SÁENZ BADILLOS, Ángel, y TARGARONA BORRÁS, Judit, Diccionario de autores judíos (Sefarad. Siglos $X-X V)$, págs. 22-24).

Sobre Abraham Zacut, véanse los estudios de CANTERA BURGOS, Francisco, Abraham Zacut. Siglo XV. Madrid, 1935 (hay reimpresión de esta obra en edición coordinada por Yolanda Moreno Koch y M. - Fuencisla García Casar, en Miranda de Ebro, Fundación Cultural "Profesor Cantera Burgos», 2008); LACAVE RIAÑO, José Luis, «El Sefer Yuhasin de Abraham Zacut» (extracto de tesis doctoral). Madrid, 1970, 47 págs. y «El carácter del Sefer Yuhasin», en Boletín de la Asociación de Orientalistas, 4 (Madrid, 1970), págs. 195-202; y GUTWIRTH, Eleazar, «The Sefer Yuhasin and Zacut's Tunisian Phase», en ROMERO, Elena (ed.), Judaísmo Hispano. Estudios en memoria de José Luis Lacave Riaño. Madrid, 2002, 2 vols. (véase en concreto vol. II, págs. 765-777). Acerca de la comunidad judía de Alba de Tormes, de donde era originario Abraham Zacut, es fundamental el estudio de GARCÍA CASAR, M. a Fuencisla, «La aljama de los judíos de Alba de Tormes», en Espacio, Tiempo y Forma. Serie III. Historia Medieval, 15 (Madrid, 2002), págs. 77-93; en él se trata, entre otras muchas cuestiones, de los orígenes del apellido Zacut.

11 Yosef Albo fue discípulo de Hasday Crescas, y participó de forma activa en 1413-1414 en la Disputa de Tortosa. En 1425 concluyó en Soria su obra Sefer ha-iqqarim (Libro de los principios), un tratado acerca de los principios fundamentales de la Ley de Moisés (SÁENZ BADILLOS, Ángel, y TARGARONA BORRÁS, Judit, Diccionario de autores judíos (Sefarad. Siglos X-XV), pág. 183).

12 CANTERA BURGOS, Francisco, «Juderías medievales de la provincia de Soria», en Homenaje a Fray Justo Pérez de Urbel, OSB. Silos, 1976, vol. I, págs. 445-482 (en concreto, véase pág. 478).

13 Son, entre otros muchos, Yishaq ibn Sadoq, más conocido como don Çag de la Maleha, almojarife mayor en tiempos de Alfonso X; Abraham ibn Sosán, almojarife de la reina con Sancho IV; Yehudah ibn Waqar en la corte de Alfonso XI; Semuel ha-Leví, tesorero mayor con Pedro I; Yuçaf Abravanel, quien ejerció funciones de embajador de Enrique II en Aragón; o Yuçaf Pichón, contador mayor («facedor de rentas en todos nuestros reinos») con Enrique II y Juan I. 
de Mendoza, mayordomo mayor del rey, como cabe deducir del comentario que sobre él hace Alvar García de Santa María en la Crónica de Juan II de Castilla:

«... con un judío que dezían don Abrahen Bienveniste, que era de Juan Furtado, fazían muchas cosas feas e desonestas en los fechos de su casa e sus regnos... que eran mucho desconplideras a su serviçio.»

Como acertadamente señala Benzion Netanyahu, si Alvar García consideraba a Abraham Bienveniste como un hombre de Hurtado de Mendoza era, sin duda, porque cumplía para él una destacada función en la administración de sus bienes ${ }^{14}$. Es muy probable que en este momento Juan Hurtado de Mendoza propusiera que Abraham Bienveniste pasara a ocupar un puesto destacado en la tesorería del reino, lo que sería aceptado por Álvaro de Luna y por el contador mayor Fernán Alfonso de Robles, quienes por entonces tenían como uno de sus principales objetivos el fortalecimiento de la hacienda real, que parecía encaminarse de forma irremediable hacia la quiebra. De este modo, Abraham Bienveniste pasaba a formar parte del séquito de Álvaro de Luna, precisamente en el momento en que éste se convertía en la cabeza del partido que hizo frente a las pretensiones de los infantes de Aragón de controlar políticamente al monarca castellano.

El relevante papel que Abraham Bienveniste pasó a desempeñar en la administración hacendística del reino fue esgrimido como uno de los argumentos justificadores del golpe protagonizado por el infante don Enrique el 12 de julio de 1420, en Tordesillas; el objetivo último de esta acción consistía en hacerse con el control de la voluntad política del monarca y apartar del gobierno del reino al mayordomo mayor Juan Hurtado de Mendoza. Como afirma Fernán Pérez de Guzmán en su Crónica de Juan II, tras la irrupción del infante don Enrique en el palacio en el que se encontraban el rey y los altos dignatarios del reino, y después de proceder al apresamiento de Juan Hurtado de Mendoza, se entabló una tensa conversación entre el rey, por una parte, y el condestable Ruy López Dávalos, el adelantado Pedro Manrique, Garci Fernández Manrique y el obispo de Segovia, Juan de Tordesillas, por la otra. Al echar el rey en cara al infante su acción, habrían intervenido el condestable y el obispo de Segovia «afeando mucho los hechos que en su casa y en sus reynos se hacían, estando todo a la gobernación de don Abrahen Bienveniste, por quien Juan Hurtado se regía» ${ }^{15}$. La razón esgrimida guardaba estrecha relación con la Pragmática de Valladolid de 1412, promulgada por la reina regente doña Catalina de Lancáster, y más en concreto con su disposición quinta, en la que se prohibía a los judíos ejercer como arrendadores,

Sobre Yuçaf Pichón véase MONTES ROMERO-CAMACHO, Isabel, «El judío sevillano don Yuçaf Pichón, contador mayor de Enrique II de Castilla (1369-1379)», en Elena ROMERO (ed.), Judaísmo Hispano. Estudios en memoria de José Luis Lacave Riaño, vol. II, págs. 561-574.

14 NETANYAHU, Benzion, Los orígenes de la Inquisición en la España del siglo XV. Barcelona. Crítica, 1999, pág. 1095, nota 10.

15 Crónica de Juan II, año 1420, capítulo II, en Biblioteca de Autores Españoles, tomo LXVIII, “Crónicas de los Reyes de Castilla» (Madrid, 1953), pág. 381b. 
procuradores, almojarifes o mayordomos del rey o de señores ${ }^{16}$. El triunfo del golpe supuso el apartamiento de la corte de los oficiales de Juan Hurtado de Mendoza, entre ellos el contador Fernán Alfonso de Robles y Abraham Bienveniste.

El 11 de agosto de 1420, y mediante un documento dado en Ávila, ciudad a la que se había trasladado la corte real a instancias del infante don Enrique, el rey Juan II se dirigía al concejo de Murcia (otras cartas idénticas se despacharían para las principales ciudades del reino de Castilla) comunicando los movimientos que habían tenido lugar recientemente en la corte, y solicitando el envío de procuradores. Esta carta, redactada por el círculo más próximo al infante don Enrique, tenía como finalidad principal justificar la toma del poder por la fuerza y contradecir las acusaciones lanzadas por el arzobispo de Toledo Sancho de Rojas, y por otras personas, contra los cabecillas del golpe de Tordesillas, a quienes acusaban de haber anulado la voluntad regia. En ella se dice textualmente lo siguiente:

«... e otrosí, los sobredichos condestable, e Garçía Ferrándes Manrrique, e el mi adelantado Pero Manrrique, con otros del mi consejo e grandes de los mis regnos que conmigo están, acatando el dicho infante don Enrrique, mi primo, el grant debdo que conmigo ha, e todos como buenos e leales vasallos lo que me eran e son tenudos asý como a su rey e señor natural, e se laudo mi serviçio e el bien público e común de los mis regnos e señoríos, con buena, e sana, e limpia entençión, considerando cómo algunos de los que estaban a çerca de mí se ovieran e avía en las cosas que a mí e a los dichos mis regnos tocavan muy mal e desordenadamente, en grant deserviçio de Dios e en grant dabño de los mis regnos e señoríos, procurando su propio interese e posponiendo del serviçio mío e el bien público de los dichos mis regnos e señoríos, faziéndolos yr por fuerça de la mi corte e del mi consejo syn cabsa legítima muchos grandes de los mis regnos e señoríos, e otros males, e dabños, e desonrras, siguiendo sus apetitos e entençiones voluntariosamente como apartando de los fechos e negoçios a los otros del mi consejo que estaban en la mi corte e conellos debían intervenir en todo ello como vendiendo e cohechando asý los ofiçios de las mis thesorerías e recabdamientos como otros ofiçios de la mi corte e casa e de las çibdades e villas de los mis regnos e señoríos de que a mí pertenesçe de proveer, e procurándolas para personas indignas e no capazes de los tales ofiçios, faziendo e trabtando todo esto e otras muchas injustiçias e desonestas e inliçitas cosas por mano de un jodío de Soria que dizen Abrahem Benveniste e por otros, procurando quel dicho jodío, en gran deserviçio de Dios e mío, e en grant escándalo de los mis regnos e aún de los regnos comarcanos, e contra los derechos e costituçiones apostólicas e leyes comunes de los mis regnos, e contra los ordenamientos en este caso fechos e establesçidos por los reyes onde yo vengo e por mí entrose e oviese lugar e perrogaun (sic) en la mi casa e corte, e aún en la mi cámara trabtando con él e por él los grandes fechos e secretos de los mis regnos e del mi consejo en que no avía muchos grandes de los dichos mis regnos ni otros del mi consejo, e espeçialmente procurando quél trabtase e librase e aviniese las dichas debdas, e alcançes, e albaquías; e otrosý que le yo diese ofiçio de recabdamien-

${ }^{16}$ La Pragmática de doña Catalina ha sido publicada, entre otros autores, por José AMADOR DE LOS RíOS, Historia social, política y religiosa de los judíos de España y Portugal. Madrid, 1875, 3 vols. (en concreto, vol. III, págs. 965-970) y por SUÁREZ BILBAO, Fernando, El fuero judiego en la España cristiana. Las fuentes jurídicas. Siglos V-XV. Madrid. Dykinson, 2000, págs. 425-430. 
tos, e que mandase que le fuesen dados e entregados presos en cadenas en su poder los fieles cristianos, mis thesoreros e recabdadores, porque los traxiese presos en su poder de un lugar a otro; e otrosý que yo librase merçedes a él e a su mujer asentadas en los mis libros. Lo qual todo redundaba en grant vitoperio de nuestra Santa Fe Católica e en grant cargo de mi concençia e era muy grant pecado e cosa de mal exenplo e difamaçión mía e de los dichos mis regnos e señoríos, e se dezía e se trataba dello en muchas partes del mundo fuera de los dichos mis regnos, e esto mesmo las dichas personas sacando de mí e apropiando de cada día para sý e para los suyos con cobdiçia desordenada muchas merçedes, e juro de eredat, e otras donaçiones puestas como no devía de los mis derechos e del mi patrimonio, e faziendo otras muchas cosas inlíçitas e injustas que sería luengo de mandar escrevir por menudo» ${ }^{17}$.

Un mes después, en septiembre de 1420 se reunían Cortes en Ávila; promovidas por el infante don Enrique, su objetivo consistía en obtener la legitimación del golpe de Tordesillas. En la sesión inaugural, Gutierre Álvarez de Toledo, por entonces arcediano de Guadalajara ${ }^{18}$, expuso los motivos para la convocatoria de las Cortes, así como las razones que justificaban la toma violenta del poder en Tordesillas:

«... e relató muy largamente todas las cosas pasadas después de la ordenanza que en Segovia se hiciera de los que debían estar con el rey para el regimiento de sus reynos, e de cómo no se había guardado; e lo que peor era, que Juan Hurtado de Mendoza, que en este tiempo era privado del rey, se regía e gobernaba por consejo de Don Abrahén Bienveniste, e todos los fechos del reyno comunicaba con él, e con su consejo se hacían muchas cosas injustas e desaguisadas e contra servicio de Dios y del rey» ${ }^{19}$.

El argumento antijudío utilizado por Gutierre Álvarez de Toledo en la inauguración de las Cortes coincidía plenamente con el que se exponía en el documento remitido por la cancillería regia a la ciudad de Murcia en agosto de 1420, y que cabe sospechar que fuera también redactado por el arcediano de Guadalajara. Focalizando la atención sobre el destacado lugar que Abraham Bienveniste ocupaba en la corte y su papel determinante en la resolución de los asuntos del reino, Gutierre Álvarez de Toledo perseguía influir en el ánimo de los procuradores de las ciudades, dejando caer que el infante don Enrique se mantenía fiel a la Pragmática de 1412 y a la posición tradicional de la Iglesia en relación con los judíos. Y los

17 Archivo Municipal de Murcia, Cartulario Real, 1411-1429, fols. 105r-v. Colección de documentos para la historia del Reino de Murcia. XVI. Documentos de Juan II, págs. 82-83.

18 Gutierre Álvarez de Toledo (también conocido como Gutierre Gómez de Toledo) era persona de gran competencia intelectual, que alcanzaría, sucesivamente, las dignidades de obispo de Palencia (2-VII-1423 - 12-V-1439), arzobispo de Sevilla (12-V-1439 - 18-VI-1442) y arzobispo de Toledo (18-VI-1442 - 4-III-1446). Intervino activamente en la política castellana desde los tiempos de la regencia de Fernando de Antequera; inicialmente tomó partido por el infante don Enrique de Aragón, y Juan II lo nombró su canciller de la «poridad». Más tarde fue un firme aliado de Álvaro de Luna (ALDEA VAQUERO, Quintín - MARÍN MARTÍNEZ, Tomás - VIVES GATELL, José (dirs.), Diccionario de historia eclesiástica de España. Madrid. CSIC, 1972-1987, 4 vols. + Suplemento; en concreto, vol. I, págs. 55-56).

19 Crónica de Juan II, año 1420, capítulo XVII, pág. 387 a-b. 
resultados fueron los esperados, por cuanto nobles, prelados y representantes de las ciudades presentes en las Cortes de Ávila aprobaron el acto de fuerza de Tordesillas. Seguidamente, el infante don Enrique se trasladó a Talavera de la Reina, al amparo de las fortalezas de la Orden de Santiago, llevando con él, en condición casi de rehén, al rey Juan II. Pero a fines del mes de noviembre, y después de haber obtenido promesas de apoyo por parte del infante don Juan y de los duques de Trastámara y Benavente, don Álvaro de Luna, quien permanecía junto al monarca, consiguió huir con él de Talavera y conducirlo al castillo de Montalbán, donde lograron resistir el asedio al que fueron sometidos durante ocho días por parte de don Enrique quien, finalmente, se vio forzado a retirarse. La victoria de Álvaro de Luna fue acompañada de un cambio radical en la composición del Consejo Real, que ahora quedaba integrado por personas adictas a don Álvaro y al infante don Juan, y supuso una nueva afirmación de la autoridad real. El ascenso político de Álvaro de Luna quedó ratificado con el otorgamiento del cargo de condestable, del que fue desposeído Ruy López Dávalos.

Entre las diversas medidas políticas adoptadas en este momento por el condestable Álvaro de Luna con el fin de favorecer la hegemonía del rey, es especialmente significativa la que propició el retorno de los judíos a la tesorería real y, sobre todo, al arrendamiento y recaudación de los impuestos, actividades que les habían sido prohibidas en la Pragmática de la regente Catalina de Lancáster de 1412. Álvaro de Luna, Juan Hurtado de Mendoza y Fernán Alfonso de Robles se encargaron de reorganizar el sistema de recaudación de impuestos, que nuevamente fue confiado, en buena medida, a arrendadores judíos ${ }^{20}$. Y es en este contexto en el que se produce el retorno de Abraham Bienveniste a la corte castellana.

En 1430 los procuradores de las ciudades y villas, reunidos en Cortes en Burgos, volvieron a reclamar al rey que se prohibiera a los judíos ejercer los oficios de arrendador y recaudador de rentas, petición que sustentaban en ciertas ordenanzas dadas por Enrique III y en el «servicio a Dios» ${ }^{21}$. Como es habitual en este tipo de peticiones, la respuesta regia fue evasiva, sin asumir ningún compromiso concreto; así, se contestó que se analizaría el contenido de esas ordenanzas y de las bulas apostólicas referidas a la misma cuestión, y que se proveería acerca de ello «commo cunple a servicio de Dios e mío». Que el monarca no tenía la más mínima intención de atender la petición de los procuradores queda de manifiesto en el hecho de que, al menos desde 1432, algunos destacados financieros judíos vinculados al círculo de Álvaro de Luna intervienen de forma activa en los arrenda-

20 Entre otros diversos autores, se han referido al importante papel desempeñado por algunos destacados financieros judíos en tiempos de Juan II de Castilla y a la vinculación existente entre estas actividades y la política proteccionista de Álvaro de Luna hacia las comunidades judías, MACKAY, Angus, «Popular Movements and Pogroms in fifteenth century Castile», en Past and Present, 55 (1972), págs. $33-67$ (véanse en concreto págs. 41-44) y MONSALVO ANTÓN, José María, Teoría y evolución de un conflicto social. El antisemitismo en la Corona de Castilla en la Baja Edad Media. Madrid. Siglo XXI, 1985, págs. 290-296.

21 Cortes de los antiguos reinos de Castilla y León. Madrid, 1861, vol. III, pág. 88, y SUÁREZ BILBAO, Fernando, El fuero judiego en la España cristiana, pág. 394. 
mientos de la «masa» de los tributos de la hacienda regia, lo que se mantuvo sin grandes alteraciones al menos hasta $1443^{22}$. Aunque en 1433 Juan II prohibió a los judíos ejercer como recaudadores de rentas reales, esta medida no les impedía la posibilidad de arrendar, lo que suponía que los judíos conservaban la capacidad de organizar la recaudación en sus niveles más importantes, como era el arrendamiento de la «masa» de las rentas del reino, el arrendamientos de los partidos o circunscripciones fiscales al «por mayor» y el arrendamiento de rentas al «por menor».

La destacada intervención de Abraham Bienveniste en los más importantes acontecimientos que marcaron la política castellana de los años veinte del siglo XV queda de manifiesto a través de la Crónica del Halconero de Juan II, de Pedro Carrillo de Huete, y de la Refundición de la Crónica del Halconero, del obispo Lope de Barrientos, quienes lo definen como «judío muy caudaloso» y como «judío bien rico e honrado", respectivamente ${ }^{23}$. Barrientos destaca la estrecha vinculación que Abraham Bienveniste tenía con el contador mayor Fernán Alfonso de Robles, lo que sin duda le permitió conocer de primera mano el funcionamiento de la compleja burocracia hacendística castellana y establecer o mejorar sus contactos con el mundo financiero del momento, ya que, como señala Pedro Carrillo de Huete, por él «pasaban todos los fechos del reyno e non se fazía ninguna cosa que algo fuese syn él». Asimismo, los dos cronistas ponen de relieve la intervención de Bienveniste como negociador durante los años 1425-1427 entre Juan II de Castilla y Alfonso $\mathrm{V}$ de Aragón, y entre los infantes de Aragón, principalmente el infante don Enrique, y «todos los otros caballeros que estaban en dibisión». En la introducción a la Crónica del Halconero de Juan II, Pedro Carrillo de Huete se refiere a estos acontecimientos del siguiente modo:

«Lunes siguiente, veinte e dos días del mes de setiembre deste año (1427), fué preso Fernán Alfonso de Robles, contador mayor del Rey de Castilla. E prendióle Ruy Díaz de Mendoça, Mayordomo mayor del señor Rey; e llevólo al alcáçar de Segobia, por mandado del Rey. El qual fue preso en Tudela (Tudela de Duero); e fue acordado de su presión en las heras de Burguillos. E esta prisión procuraron muchos cavalleros, por enojo que dél tenían de los hechos pasados; e asymismo por quanto el señor Rey le dio mucha fee syenpre, e rrecelavan que les empacharía mucho sy allý estubiese. E al señor Rey plogó de su prisión, e dió lugar a ello, porque fué en dar sentençia para que el condestable saliese de la corte.

Este día, lunes, veinte y dos días de setiembre, fué preso en la dicha Tudela don Abrahén Bienveniste, judío muy caudaloso, el qual avía dos años que hera puesto por tratador en todos los devates que eran entre el señor Rey e el rrey de Aragón su primo. Eso mysmo era tratador entre los fechos del ynfante don Enrrique e de todos los otros caballeros que estaban en dibisión. E este don

22 ORTEGO RICO, Pablo, Hacienda, poder real y sociedad en Toledo y su Reino (siglo XV-principios del XVI), vol. II, págs. 870-871.

23 CARRILLO DE HUETE, Pedro, Crónica del Halconero de Juan II. Edición y estudio de Juan de Mata Carriazo. Granada. Universidad de Granada, 2006 pág. 14, y BARRIENTOS, Lope de, Refundición de la Crónica del Halconero. Edición de Juan de Mata Carriazo. Madrid. Espasa Calpe, 1946, pág. 35. 
Abrahén fue preso en poder de Pero Carrillo de Huete, falconero mayor del señor Rey, por mandado del dicho señor Rey» ${ }^{24}$.

Como pone de manifiesto Luis Suárez Fernández, estos acontecimientos se enmarcan en los hechos que condujeron al primer destierro de Álvaro de Luna en 1427. Los infantes de Aragón, con el rey Juan de Navarra a la cabeza, trataron de ganarse el apoyo de la nobleza castellana, descontenta con la política absolutista desplegada por el Condestable, en tanto que éste trató de hacerse con el apoyo de la burguesía ciudadana a través de las Cortes; asimismo, los infantes lograron atraer a su bando al contador Fernán Alfonso de Robles, quien hasta entonces había sido hombre de confianza de Álvaro de Luna. Las discordias políticas tuvieron en este momento su centro de atención en torno a la composición del Consejo Real, ya que si el Condestable confiaba en que haciendo uso de este órgano conseguiría imponer su autoridad, los infantes aspiraban a lograr a través de él el poder compartido. El 10 de febrero de 1427 los aragoneses lograron conformar una liga nobiliaria; aunque entraron a formar parte de ella las tres Órdenes Militares, que constituían la principal fuerza militar del reino, de momento la mayor parte de la nobleza se mantuvo neutral, esperando a ver por qué bando se decantaba la victoria 25

Durante algunas semanas el Condestable dudó entre rendirse o hacer frente, pero acabó decidiéndose por la negociación, en el convencimiento de que no disponía de fuerzas suficientes para vencer en combate; el acuerdo alcanzado entre las partes en disputa consistió en encomendar a una comisión arbitral la resolución del problema político. La comisión estaba presidida por el prior del monasterio de San Benito de Valladolid, y formaban también parte de ella el almirante de Castilla y el contador Fernán Alfonso de Robles por parte de don Álvaro, y el maestre de Calatrava y el adelantado Pedro Manrique por parte de los infantes; el prior de San Benito de Valladolid haría las veces de mediador en caso de empate. Debido a la traición de Fernán Alfonso de Robles, la comisión determinó el destierro de Álvaro de Luna de la corte por un tiempo de año y medio. El Condestable se instaló en Ayllón, en tanto que el infante don Juan trataba de controlar el Consejo mediante el nombramiento de personas adictas a su persona. Fernán Alfonso de Robles, quien con su traición había hecho posible la sentencia desfavorable para don Álvaro, quizá aspirando a ocupar la parcela de poder que quedaría vacante tras su salida de la corte ${ }^{26}$, fue preso el 22 de septiembre y murió en Uceda sin

24 CARRILLO DE HUETE, Pedro, Crónica del Halconero de Juan II, pág. 14.

25 SUÁREZ FERNÁNDEZ, Luis, «Los infantes de Aragón y Don Álvaro de Luna (1416-30)», págs. 100-101.

${ }^{26}$ Así lo narra el cronista Gonzalo Chacón en su Crónica de D. Álvaro de Luna:»...de aqueste Fernando Alonso de Robles se fiaba el Condestable más que de otra persona alguna. E aqueste Fernando Alonso, pensando que si el Condestable se partía de la corte que el consejo e mando de las cosas quedaría en él, porque el rey ge lo daría por ser tanto del Condestable, trató con los otros jueces, que dicho avemos, que declarasen por su sentencia que el Condestable se partiesse de la corte". Gonzalo CHACÓN (edición de Juan de Mata Carriazo y Arroquia), Crónica de don Álvaro de Luna. Madrid. Espasa Calpe, 1940, págs. 50-51. 
recobrar la libertad; los bienes que tenía depositados en el convento de San Benito de Valladolid fueron confiscados. El mismo día 22 de septiembre fue encarcelado Abraham Bienveniste y puesto bajo la custodia del halconero Pedro Carrillo de Huete, pues era persona adicta al contador.

Los relatos de los tres cronistas -Pedro Carrillo de Huete, Lope de Barrientos y Gonzalo Chacón- parecen confirmar el vínculo mantenido durante los años veinte por Abraham Bienveniste con el partido del Condestable, lo que queda ratificado dos años después, en 1429, una vez que Álvaro de Luna ya había recobrado el poder, con ocasión de la guerra de Castilla con Aragón. En el transcurso de las operaciones bélicas, Abraham Bienveniste realizó un préstamo de 150.000 maravedíes a la hacienda regia, con el fin de pagar a la gente que estaba en la frontera castellana con Aragón; asimismo intervino don Abraham en la venta de 2.000 fanegas de pan ordenada por el rey Juan II en la misma frontera, en el marco de la movilización de tropas que había sido llevada a cabo en aquella ocasión ${ }^{27}$. Probablemente, la guerra de 1429 con Aragón, el fin temporal de la influencia de los infantes de Aragón en la corte castellana y el retorno al poder de Álvaro de Luna permitieron a Abraham Bienveniste afianzar la privilegiada posición que le vinculaba financieramente con el Condestable y consolidar su posición en el entramado hacendístico del reino a lo largo de los años treinta del siglo $\mathrm{XV}^{28}$.

Además de en las crónicas del reinado de Juan II de Castilla, es posible encontrar algunas referencias acerca de la personalidad de Abraham Bienveniste en el Sebet Yehudah (La vara de Judá), una crónica hispano-hebrea redactada en su parte principal por Selomoh ben Verga en los primeros decenios del siglo XVI ${ }^{29}$. Aunque no es fácil discernir cuánto hay de verdad y cuánto de imagen propagandística, Selomoh ben Verga nos presenta a Abraham Bienveniste y a otras destacadas figuras del judaísmo castellano de su tiempo como personas que, pese a su privilegiada posición económica, se comportaban con modestia en sus actitudes externas. Así, en una de las conversaciones imaginarias que entre diversos reyes de Castilla y algunas de las personalidades de la comunidad judía se insertan a lo largo de la crónica, el rey reprendía a los judíos por lo que calificaba de soberbia en sus actitudes

27 AGS, Escribanía Mayor de Rentas (en adelante EMR), leg. 1, fols. 104-105.

28 ORTEGO RICO, Pablo, Hacienda, poder real y sociedad en Toledo y su Reino (siglo XV-principios del XVI), vol. II, págs. 872-873.

29 Selomoh ben Verga, médico e historiador judío, alcanzó gran notoriedad en la aljama sevillana de los últimos decenios del siglo XV. Con anterioridad a la expulsión de 1492 emigró a Lisboa, ciudad en la que residió en calidad de converso hasta el año 1507 cuando, con ocasión de la matanza de judeoconversos que tuvo por escenario la ciudad lisboeta en 1506, se trasladó a Turquía, fijando su residencia en Adrianópolis, la actual Edirne, ciudad donde compuso la mayor parte del Sebet Yehudah. La compilación llevada a cabo por Selomoh ben Verga fue completada por su hijo Yosef, quien vivió en Adrianópolis en la primera mitad del siglo XVI, ciudad en la que ejerció como rabino y como dayyán o juez.

Disponemos de dos excelentes traducciones españolas del Sebet Yehudah: la clásica de Francisco Cantera Burgos: Chébet Jehuda (La Vara de Judá) de Salomon Ben Verga. Traducción española con un estudio preliminar por Francisco Cantera Burgos. Granada, 1927, y la más reciente de María José Cano: Selomoh IBN VERGA, La Vara de Yehudah (Sefer Sebet Yehudah). Introducción, traducción y notas por María José Cano. Barcelona. Riopiedras Ediciones, «Biblioteca Nueva Sefarad», vol. XVI, 1991. 
y por ser portadores de vestimentas propias de personas del estamento aristocrático, ante lo que Benveniste el Viejo (Rabí Abraham Bienveniste) habría respondido:

«Precisamente esa es la soberbia, pues el humillado procura ser respetado por medio de vestidos magníficos para no caer completamente. Además, nuestro señor, sólo visten ropas caras los jóvenes y las mujeres, y buscar razocinio en los jóvenes y las mujeres es como buscar zorros en el mar y peces en la tierra. ¿Acaso has visto nuestro rey que yo, tu servidor, y toda la administración de Castilla que está en mi mano haya vestido de seda?»30.

Y algo parecido habrían respondido al rey en otra ocasión don Abraham Bienveniste, don Yosef ha-Nasíi ${ }^{31}$ y Rabí Semuel ben Sosán, algunos de los más destacados representantes de la comunidad judía castellana:

«Nosotros, siendo mensajeros de tu pueblo y los más ricos del nuestro, henos aquí con vestidos negros y de poco valor, ¿no era una razón para llegar a la puerta del rey con ropajes caros?» 32 .

En otros escritos del siglo XV se presenta a Abraham Bienveniste como un firme defensor de posiciones bastante conservadoras en la interpretación de la Ley judía y opuesto a todo tipo de exégesis alegórica de la Ley. Así, Rabí Hayyim ibn Musa ${ }^{33}$, en su Séfer Maguén wa-rómah («Libro del escudo y la lanza»), relata cómo en cierta ocasión que dos jóvenes rabinos discutían en presencia de Abraham Bienveniste acerca de la oportunidad del método de exégesis alegórica en la interpretación de las Escrituras, el Rab Mayor mostró su oposición radical al mismo y su profundo desprecio hacia quienes hacían uso de él:

«Hasta que el rab se puso en pie bramando contra su polémica y dijo: "Soy todo paz; mas si hablo, ellos por la guerra están"(Salmos, 120, 7). Y dirigiéndose a la comunidad dijo: "Hermanos míos, hijos de Abraham, creed que cuando el versículo dice 'En el principio creó Dios'o 'Salió Jacob de Beersheba', esto es así, literalmente, y asimismo todo lo que viene en la Torá y que aclararon y mantuvieron como tradición nuestros maestros, de bendita memoria, no como dicen estos irritantes charlatanes"» 34 .

\footnotetext{
30 IBN VERGA, Selomoh, La Vara de Yehudah (Sefer Sebet Yehudah). Introducción, traducción y notas por María José Cano, capítulo 70, pág. 275.

31 Yitzhak Baer considera que puede tratarse de don Yuçaf Nasí, vecino de Medina de Pomar, uno de los financieros judíos más importantes del primer tercio del siglo XV, al que luego se hará referencia más detenida: BAER, Yitzhak, Historia de los judíos en la España cristiana. Madrid. Altalena, 1981, 2 vols. (traducción de J. L. Lacave), vol. II, pág. 515 (nueva edición en Barcelona. Riopiedras Ediciones, 1998).

32 IBN VERGA, Selomoh, La Vara de Yehudah (Sefer Sebet Yehudah), capítulo 8, pág. 76.

33 Hayyim ben Yehudah ibn Musa (c. ${ }^{\text {a }}$ 1380-1460) era originario de Béjar y sirvió durante cuatro decenios como médico en la corte castellana, alcanzando un gran prestigio profesional. Fue también comentarista bíblico, poeta litúrgico y polemista, y combatió el racionalismo y el averroísmo, corrientes de pensamiento que consideraba muy peligrosas porque podían socavar los cimientos del judaísmo (SÁENZ BADILLOS, Ángel, y TARGARONA BORRÁS, Judit, Diccionario de autores judíos (Sefarad. Siglos X-XV), pág. 51).

34 BAER, Yitzhak, Historia de los judíos en la España cristiana, vol. II, pág. 516 y pág. 765, nota 19.
} 


\section{ABRAHAM BIENVENISTE, RAB MAYOR DE LOS JUDÍOS DE CASTILLA}

La proximidad de Abraham Bienveniste a la corte y al valido real Álvaro de Luna fueron, con toda seguridad, las razones que explican su nombramiento como Rab Mayor de la corte o Rab Mayor de los judíos de Castilla, una figura institucional que, probablemente, ya existiera con otro nombre en la segunda mitad del siglo XIII, y que conoció su pleno desarrollo a partir de la segunda mitad del siglo XIV; tenía funciones principalmente de carácter judicial y, secundariamente, de índole fiscal. El desempeño de esta alta magistratura, al que se accedía por nombramiento regio, comportaba la autoridad máxima sobre todos los judíos del reino. Además de cabeza de la administración de justicia propia de la comunidad judía, el Rab Mayor tenía también entre sus competencias la distribución entre las aljamas del reino de las cantidades que la hacienda regia asignaba a la minoría judía en concepto de tributos especiales directos («cabeza de pecho» y «servicio y medio servicio» ${ }^{35}$ ). El Rab Mayor actuaba también en todo momento como mediador entre la corona y la comunidad judía, y era siempre una persona de confianza del rey y de la corte ${ }^{36}$.

El momento en el que iba a desarrollarse la acción de Abraham Bienveniste como Rab Mayor de los judíos de Castilla era de especial relevancia para la comunidad judía castellana, por cuanto las nuevas circunstancias históricas que comenzaban a vislumbrarse podían permitir una cierta recuperación, después de la crítica situación en la que había quedado como consecuencia de las persecuciones de 1391 y de la durísima legislación antijudía de los primeros años del siglo XV. Una recuperación que, como sostiene Yitzhak Baer, necesariamente había de pasar por el fortalecimiento de la religión como base de la tradición heredada y la restauración de las instituciones públicas propias del judaísmo; una empresa a la que Abraham Bienveniste se entregó desde el primer momento con entusiasmo y fortaleza de ánimo.

El 26 de noviembre de 1431, y mediante una carta otorgada en Medina del Campo, el rey Juan II procedió al nombramiento de Abraham Bienveniste como Rab Mayor de los judíos de Castilla, recuperando una figura que había quedado vacante dos decenios antes, tras la muerte de don Meir Alguadex, quien había

\footnotetext{
${ }^{35}$ Véase sobre este particular el estudio de LADERO QUESADA, Miguel Ángel, "Las juderías de Castilla según algunos servicios fiscales del siglo XV", en Sefarad, XXXI (1971), págs. 249-264.

${ }^{36}$ Acerca de la figura del Rab Mayor pueden consultarse, entre otros estudios, los de NEUMANN, Abraham A., The Jews in Spain: Their Social, Political and Cultural Life during the Middle Ages. Filadelfia, 1944, 2 vols. (en concreto, vol. I, pág. 60, y vol. II, pág. 265 y ss.); GUTWIRTH, Eleazar, «Hacia la expulsión: 1391-1492», en KEDOURI, Elie (ed.), Los judíos de España. La diáspora sefardí desde 1492. Traducción española de Mireia Carol. Barcelona. Editorial Crítica, 1992, págs. 47-97 (véanse en concreto págs. 59-62); CASTAÑO, Javier, «Tensiones entre las comunidades judías y la monarquía en Castilla, c.1447-1474: el nombramiento del Juez Mayor de las aljamas", en CARRETE PARRONDO, Carlos, y MEYUHAS GINIO, Alisa (eds.). Salamanca, 1998, págs. 11-20; y CRESPO ÁLVAREZ, Macarena, «E cargo de Rab Mayor de la Corte según un documento de Juan II fechado en 1450", en Edad Media. Revista de Historia, 4 (2001), págs. 157-198.
} 
ejercido el cargo desde su nombramiento por el rey Juan I, el 25 de marzo de 1386, hasta su muerte en $1410^{37}$. Las escrituras de nombramiento de Meir Alguadex y Abraham Bienveniste como Rab Mayor se contienen en un traslado simple de un total de ocho documentos que fue realizado el 26 de octubre de 1450, en Medina del Campo, a petición de Sem Tob Alpullate, vecino de Alcalá de Henares y por entonces procurador de las aljamas de los judíos de Castilla, ante el maestre Francisco, alcalde de Medina del Campo ${ }^{38}$. Como es habitual en este tipo de nombramientos, el rey Juan II argumentaba que los motivos que le movían a designar a Abraham Bienveniste eran los buenos servicios que le había prestado a él, y procurando el bien propio y el de las aljamas de los judíos del reino: «...por muchos buenos servicios que me avedes fecho e fazedes, e porque cunplen asý a mi servicio e pro, commo de las aljamas de los judíos de los mis regnos e señoríos» ${ }^{39}$. El nombramiento, con carácter vitalicio, se otorgaba con validez para todas las aljamas del reino, y comportaba las mismas atribuciones de que había gozado don Meir Alguadex, entre ellas la de percibir todos los derechos y salarios que le correspondían por razón del desempeño de este oficio.

En su exhaustivo estudio acerca de la figura del Rab Mayor de los judíos de Castilla, Macarena Crespo apunta la posibilidad de que la carta de nombramiento de Abraham Bienveniste fuera otorgada en el año 1421. Así, señala esta autora que en el traslado de la carta de 26 de noviembre que se conserva en el Archivo Municipal de Guadalajara no se lee bien el año del documento, y que aunque parece leerse «quarenta», al estar inserta en una carta de 1431 es probable que el escribano autor de la copia confundiese la fecha del año; además, debido a que el

${ }_{37}$ Meir Alguadex fue médico de los reyes de Castilla desde tiempos de Juan I y Rab Mayor de los judíos de este reino desde 1386; asimismo es probable que tuviera a su cargo tareas financieras de la corona. Tras los asaltos a las juderías en 1391, y en su condición de dirigente de la comunidad judía castellana, sus esfuerzos se concentraron en la restauración de las aljamas que más habían sufrido las consecuencias de la persecución. Es mencionado de forma muy elogiosa en las Taqqanot de Valladolid de 1432.

Aunque se desconoce la verosimilitud de la información, según recoge fray Alonso de Espina en su Fortalitium fidei, obra compuesta en torno al año 1460, en 1410 don Meir Alguadex fue acusado junto a otros judíos de participar en la profanación de una Hostia consagrada en Segovia. En el proceso promovido por el obispo Juan de Tordesillas, y tras ser sometido a tormento, Meir Alguadex habría confesado su participación en dicha profanación; sentenciado a pena de muerte, fue ahorcado, arrastrado por la ciudad y descuartizado (Fortalitium fidei, Libro tercero, consideración décima, décimo milagro, fols. 223 r.은 223 v.․․ Esta misma noticia la refiere también el cronista hispano-hebreo HA-KOHEN, Yosef, en su obra titulada EI Valle del Llanto (Emeq ha-Bakha). Crónica hebrea del siglo XVI. Introducción, traducción y notas por Pilar León Tello. Barcelona. Riopiedras Ediciones, 1989, pág. 113 (1. a ed. en Madrid-Barcelona. C. S. I. C., 1964).

Sobre el Fortalitium fidei, véase Fontes Iudaeorum Regni Castellae. VIII. Alisa MEYUHAS GINIO, De bello iudaeorum. Fray Alonso de Espina y su Fortalitium Fidei. Salamanca, 1998.

Sobre Meir Alguadex, véase GARCÍA BALLESTER, Luis, La búsqueda de la salud. Sanadores y enfermos en la España medieval. Barcelona, 2001, págs. 124 y passim.

38 Este amplio traslado documental, que se guarda en el Archivo Municipal de Guadalajara (en adelante AMGU - sig. 136544, Cuaderno), ha sido transcrito por CRESPO ÁLVAREZ, Macarena, «El cargo de Rab Mayor de la Corte según un documento de Juan Il fechado en 1450», págs. 179-198.

39 AMGU, sig. 136544, Cuaderno, fol. 6v.ํ, CRESPO ÁLVAREZ, Macarena, «El cargo de Rab Mayor de la Corte según un documento de Juan II fechado en 1450», pág. 184. 
mes de la data es noviembre y la carta en la que está inserta es de septiembre, considera que tampoco es probable que el año sea 1431, por lo que plantea la hipótesis de que, en realidad, la carta fuera dada el año 142140. Sin embargo, en mi opinión, lo más probable es que la carta fuera otorgada en el año 1431, por la razón que expongo seguidamente. Como sabemos que la carta de nombramiento regio fue dada en la ciudad de Medina del Campo, se trataría de comprobar en qué año - 1421, 1431 o 1441 - la corte castellana se encontraba en Medina del Campo el día 26 de noviembre. Por lo que respecta al año 1421, la Crónica del rey Juan II nos informa de que el día 23 de octubre la corte se estableció en Toledo ${ }^{4}$, donde permaneció de forma ininterrumpida hasta mediados del mes de marzo de $1422^{42}$. Por el contrario, en el año 1431 la corte se estableció en Medina del Campo el día 19 de septiembre ${ }^{43}$, permaneciendo en esta ciudad por lo menos hasta el día 27 de noviembre ${ }^{44}$; el día 30 de noviembre la corte estaba ya en Zamora, ciudad en la que permaneció, con alguna ausencia momentánea, hasta el 19 de febrero de 1432, cuando se trasladó a Toro ${ }^{45}$.

La explicación de que el documento de 26 de noviembre de 1431 esté inserto en otro teóricamente anterior, de fecha 11 de septiembre de 1431, se encontraría, en mi opinión, en que la fecha anotada en el traslado documental está equivocada y que la fecha correcta sería el 11 de diciembre de 1431. En este documento el monarca exigía a todo el reino, incluidas las aljamas judías, que se respetara en su oficio de Rab Mayor de los judíos a Abraham Bienveniste, quien gozaría de la misma autoridad, jurisdicción y prerrogativas que habían sido concedidas por sus antecesores Juan I y Enrique III a Meir Alguadex ${ }^{46}$. Incluso desde el punto de vista del orden de emisión de los documentos, parece lógico que en primer lugar se procediera al nombramiento de Abraham Bienveniste para el cargo de Rab Mayor y que unos días después se emitiera la orden regia dirigida a todas las comunidades judías del reino para que le recibieran en el cargo. Tan sólo un día después de la supuesta fecha de emisión de esta última carta, el 12 de diciembre de 1431, se acordaba en Zamora el arrendamiento en «masa» de las alcabalas y tercias del reino correspondientes al trienio 1432-1434; en esta ocasión el rey se encontraba

40 CRESPO ÁLVAREZ, Macarena, «El cargo de Rab Mayor de la Corte según un documento de Juan II fechado en 1450», pág. 185, nota 68.

41 Crónica de Juan II, año 1421, capítulo XXXIII, pág. 411a.

42 Crónica de Juan II, año 1422, capítulos VI y VII, págs. 414b-415a.

43 Crónica de Juan II, año 1431, capítulo XXIII, pág. 500b. Así lo confirma también CAÑAS GÁLVEZ, Francisco de Paula, El itinerario de la corte de Juan Il de Castilla (1418-1454). Madrid. Sílex, 2007, págs. 267-268.

${ }^{44}$ Crónica de Juan II, año 1431, capítulos XXVII y XXVIII, pág. 502a. CAÑAS GÁLVEZ, Francisco de Paula, El itinerario de la corte de Juan Il de Castilla (1418-1454), págs. 267-268, cita diversas referencias documentales a través de las que consta la presencia de la corte castellana en Medina del Campo los días 25 y 27 de noviembre de 1431.

45 CAÑAS GÁLVEZ, Francisco de Paula, El itinerario de la corte de Juan Il de Castilla (1418-1454), págs. 268-272.

${ }^{46}$ La carta es transcrita por CRESPO ÁLVAREZ, Macarena, «El cargo de Rab Mayor de la Corte según un documento de Juan II fechado en 1450», págs. 184-193. 
acompañado de Álvaro de Luna, del conde de Benavente Rodrigo Alonso Pimentel, del adelantado mayor de Castilla Pedro Manrique y de Pedro de Estúñiga, entre otros nobles ${ }^{47}$.

Por último, tampoco sería posible que la carta de nombramiento de Abraham Bienveniste como Rab Mayor hubiera sido otorgada el día 26 de noviembre de 1441, pues la corte castellana se trasladó desde Valladolid a Toro en fecha incierta comprendida entre el 17 y el 25 de noviembre de este año, permaneciendo en esta localidad zamorana al menos desde el 25 de noviembre de 1441 hasta el 17 de febrero de $1442^{48}$.

En su condición de Rab Mayor de los judíos de Castilla, Abraham Bienveniste convocó para los últimos días del mes de iyyar ${ }^{49}$ de 1432 («la última decena del mes de iyyar del año antes mencionado, ciento noventa y dos de la era de la Creación ${ }^{50}$ ») a los delegados y a los rabinos ${ }^{51}$ de las principales aljamas judías de Castilla y a algunos «omes buenos que andan en la corte de nuestro señor el rey», para la celebración de una asamblea que tendría lugar en Valladolid, ciudad en la que por aquel tiempo residía la corte castellana. La reunión se celebró en la sinagoga mayor de Valladolid, probablemente entre los días 20 de abril y 2 de mayo, y tuvo como objetivo principal la redacción de unas ordenanzas o taqqanot ${ }^{52}$ que sirvieran como norma de gobierno general para todas las comunidades judías castellanas; con ellas se buscaba dotar al judaísmo castellano de una estructura orgánica de la que carecía y favorecer la restauración de sus comunidades a su estado anterior a las persecuciones de 1391; fueron aprobadas por unanimidad el día 1 del mes de siván ${ }^{53}$. Escritas en castellano con caracteres hebreos, ofrecen una muy interesante información acerca del estado de las comunidades judías castellanas en el primer tercio del siglo XV; han sido editadas magníficamente por Yolanda Moreno

\footnotetext{
47 AGS, Cámara de Castilla, Diversos, leg. 4, doc. 60. ORTEGO RICO, Pablo, Hacienda, poder real y sociedad en Toledo y su Reino (siglo XV-principios del XVI), vol. II, pág. 865.

48 CAÑAS GÁLVEZ, Francisco de Paula, El itinerario de la corte de Juan II de Castilla (1418-1454), págs. 356-357.

49 Octavo mes del calendario civil judío, y segundo del litúrgico. Tiene veintinueve días, y su comienzo oscila entre el 12 de abril y el 11 de mayo.

50 Se refiere al año 5192 de la era de la Creación, que corresponde al año 1432.

51 Los rabinos son nombrados como talmide hakamim o «estudiantes rabínicos»; talmid hakam es un título honorífico que estaba reservado para quien se dedicaba al estudio de la Ley y era un experto conocedor del Talmud.

Una excelente aproximación a la estructura de las aljamas judías hispanas puede verse en el estudio de MORENO KOCH, Yolanda, «Organización interna de las aljamas judías en la Edad Media», en El legado de los judíos al Occidente europeo. De los reinos hispánicos a la monarquía española. Pamplona. Gobierno de Navarra-Universidad Pública de Navarra, 2002, págs. 137-144.

52 Término hebreo que significa «estatutos». Consisten en decisiones rabínicas que tienen valor de ley, sin apelación posible. Con frecuencia responden a necesidades circunstanciales de una comunidad judía, y afectan tan sólo a ella, consistiendo en un reglamento o, sencillamente, en una prescripción. La gran importancia de las taqqanot de Valladolid de 1432 es que se aprobaron con valor de ley para todas las comunidades judías del reino de Castilla.

53 Noveno mes del calendario civil judío, y tercero del litúrgico. Tiene treinta días, y su comienzo oscila entre el 11 de mayo y el 9 de junio.
} 
Koch, con un muy interesante estudio previo ${ }^{54}$. En sus distintos capítulos se abordan temas tan relevantes como el fomento del estudio de la Torá, la elección de jueces y otros cargos de las aljamas, la defensa de la comunidad frente a las denuncias de los malsines ${ }^{55}$, la regulación de los impuestos y servicios que habían de satisfacer los judíos o la exhortación a la modestia en el vestir, animándose a las comunidades a una estricta observancia de la Ley judía. La importancia que tuvieron las taqqanot de Valladolid en la evolución del judaísmo castellano a lo largo del siglo XV está fuera de toda duda, ya que constituyen el instrumento con el que los sucesivos dirigentes de la comunidad judía castellana, a través de la acción de los líderes de las aljamas locales, lograron la restauración del judaísmo castellano y su perduración hasta los tiempos de la expulsión de 1492.

A lo largo del texto de las taqqanot hay diversas alusiones a Abraham Bienveniste, a través de las que se hace patente el gran prestigio de que gozaba en el seno de la comunidad judía castellana y la relevancia que a su función se concedía por parte de la corona.

El capítulo segundo está dedicado a la elección de los jueces y de otros diversos oficiales de las aljamas. Habiéndose comprobado que algunas comunidades judías no disponían de jueces propios encargados de sentenciar en las causas internas, se ordenaba que en el plazo de diez días desde que las taqqanot se hicieran públicas cada comunidad, reunida en asamblea general, habría de elegir jueces; y por procedimientos similares deberían ser elegidos los demás cargos públicos de las aljamas. En el caso de que no se llegara a un acuerdo para la elección de los distintos cargos habría de informarse al Rab Mayor, quien procedería a su designación. Pese a que se confería autoridad a los jueces locales para multar y castigar a quienes fueran declarados culpables, se garantizaba el derecho de apelación de las sentencias ante el Rab Mayor, lo que, en su caso, permitiría reparar posibles agravios e injusticias de los tribunales locales ${ }^{56}$ :

"Otrosí ordenamos que los jueces que son o fueren encargados en cada qahal ${ }^{57}$, todo el tiempo de esta taqqanah puedan e ayan poder pora judgar e

54 MORENO KOCH, Yolanda, Fontes Iudaeorum Regni Castellae. V. De iure hispano-hebraico. Las Taqqanot de Valladolid de 1432. Un estatuto comunal renovador. Salamanca. Universidad Pontificia de Salamanca-Universidad de Granada, 1987.

55 Se conoce con el nombre de malsín al judío que calumniaba o delataba falsamente a correligionarios suyos. El delito de malsindad se castigaba por los tribunales judíos con penas severas.

${ }^{56}$ No fueron infrecuentes a lo largo del siglo XV las apelaciones ante el Rab Mayor e, incluso, en el último cuarto del siglo XV se constata documentalmente cómo muchos judíos pleiteaban ante las justicias regia y concejil, haciendo caso omiso de las recomendaciones de las autoridades judías de acudir siempre ante los jueces de las aljamas, lo que obedecía a la suspicacia de los judíos de condición más sencilla hacia los jueces propios, a los que consideraban demasiado sujetos a las presiones de las familias más poderosas (véase sobre este particular el trabajo de CANTERA MONTENEGRO, Enrique, «La justicia en las aljamas castellanas a fines del siglo XV: la frontera oriental del reino de Castilla», en Sefarad, LII (1992), págs. 337-353).

57 Término hebreo que significa, literalmente, «congregación» o «asamblea» (en plural, qehil.lot). Con él se designa tanto a las comunidades judías de carácter local como a la asamblea de todo el pueblo de Israel. 
judguen entre un hombre y entre su hermano y su prójimo todos los pleitos e contiendas e querellas que ubiere entre ellos, según veredicto del Talmud; e puedan multar y castigar al transgresor, según Talmid Hakam y tres hombres entre los buenos de la ciudad, de los más honrados, que conozcan la ley y el derecho, de entre los habitantes de aquel lugar; todavía guardando la regla e probilejo de la merçed que nuestro senior el rey, Dios le guarde, fizo al dicho Rab don Abraham, Dios le guarde, en la dicha razón, e todavía finque asalvo acual quiere que se agrabiare de cualquiere juicio que fuere dado contra él e pidiere apelación o apelare ante el dicho Rab, Dios le guarde, que jela otorguen faziendo las diligençias que delante de esta razón serán declaradas» ${ }^{58}$.

En el capítulo tercero se trata el tema de las denuncias, y en él se hace referencia al siempre espinoso asunto de la malsindad, recogiéndose distintas disposiciones contra los actos de coacción hacia particulares o hacia instituciones públicas, tales como la celebración de esponsales o matrimonios forzados por el rey o por señores poderosos o violentos, la intromisión de cristianos poderosos en la venta de vino en el barrio judío, o la obtención de nombramientos o cargos en la aljama con la mediación del rey o de señores poderosos no judíos. Pero de esta norma se exceptuaba a don Abraham Bienveniste:

«Pero esta ordenanza non atanie nin pueda atanier al dicho honrado Rab don Abraham, Dios le guarde, por quanto el deseo de la generalidad de los qehil.lot, guárdeles su Roca y su Salvador, era e es que él fueese su juez mayor e su repartidor; e a pedimiento de Talmide Hakamim e a seguimiento de qehil.lot, guárdeles su Roca y su Salvador, e por sus peticiones le ganó, y por su asentimiento açeptó el dicho judgado e repartidor. E cualquiere otro que merçed alguna tuviere ganada de lo que dicho es, ordenamos que la den en poder del dicho honrado Rab don Abraham, Dios le guarde, de aquí fasta seis meses siguientes, pora quél vea las dichas cartas e lo que en ello se debe fazer e lo faga; y durante este tiempo, si quiere usar de su ofiçio, según su costumbre, por poder de la tal merçed, pueda, y su recompensa sea a juicio del Rab mencionado, Dios le guarde ${ }^{59}$.»

La asamblea de Valladolid en la que se aprobaron las Taqqanot de 1432 coincide con el decenio en el que Álvaro de Luna alcanzó la plenitud de su poder, por lo que cabe sospechar que el valido real tuviera también algo que ver en la iniciativa para la convocatoria de la reunión. Otras destacadas figuras de la asamblea, que firmaron en testimonio de confirmación de lo acordado, son Yishaq ha-Kohén ben Crispin y Baruk ben Abraham ben Çahal.

Abraham Bienveniste ocupó el cargo de Rab Mayor de los judíos de Castilla hasta su muerte, siendo nombrado en su lugar el camarero real Pedro de Luján. El nombramiento de Luján como Rab Mayor contó con la oposición radical de las aljamas del reino, alegando su condición de cristiano. $Y$ tan fuerte fue la reacción que el rey Juan II, por carta dada en Arévalo el 28 de agosto de 1450, le cesó en

\footnotetext{
58 MORENO KOCH, Yolanda, Fontes Iudaeorum Regni Castellae. V. De iure hispano-hebraico. Las Taqqanot de Valladolid de 1432. Un estatuto comunal renovador, pág. 41.

59 MORENO KOCH, Yolanda, Fontes Iudaeorum Regni Castellae. V. De iure hispano-hebraico. Las Taqqanot de Valladolid de 1432. Un estatuto comunal renovador, pág. 69.
} 
el oficio, cediendo a las aljamas del reino los oficios del juzgado mayor y menor y la función de repartimiento de los servicios y medios servicios, para que propusieran las personas que consideraran idóneas para su desempeño, de entre las que el rey elegiría la mitad ${ }^{60}$. Pese a que no consta documentalmente la fecha del nombramiento de Pedro de Luján como Rab Mayor, en mi opinión no debió mediar mucho tiempo entre su nombramiento y su cese, por lo que cabe suponer también que la muerte de Abraham Bienveniste habría tenido lugar a fines del año 1449 o a comienzos de 1450 .

\section{ABRAHAM BIENVENISTE COMO TESORERO Y FINANCIERO AL SERVICIO DE LA CORONA}

Además de su faceta como dirigente de las comunidades judías castellanas, al analizar la figura de Abraham Bienveniste es obligado hacer referencia a su destacada intervención en tareas de gestión en la hacienda real castellana. La documentación que se ha conservado nos presenta a Abraham Bienveniste como un gran experto en las complejas cuestiones que competían al mundo de las finanzas. Esta fue la razón, muy probablemente, que motivó su llamamiento a la corte en el año 1420, y que desde entonces Álvaro de Luna no prescindiera de sus servicios.

Con ocasión de la corta guerra que en el año 1429 el rey Juan II de Castilla y Álvaro de Luna mantuvieron con el rey de Aragón Alfonso V y con sus hermanos, los infantes de Aragón, Abraham Bienveniste tuvo un destacado papel en la financiación de las operaciones bélicas y del avituallamiento de las tropas, junto con el también judío don Yuçaf Nasí, vecino de Medina de Pomar, una figura de gran relieve en relación con las finanzas de la Casa de Velasco y de la corona castellana a lo largo del segundo y tercer decenios del siglo $\mathrm{XV}^{61}$.

A lo largo del verano de 1429 tuvieron lugar diversos combates fronterizos, que posibilitaron a los castellanos la ocupación de las localidades de Monreal y Ariza. Pero concluido el verano, y siendo necesarias las tropas en el interior del

60 Esta carta es transcrita por CRESPO ÁLVAREZ, Macarena, «El cargo de Rab Mayor de la Corte según un documento de Juan II fechado en 1450», págs. 180-194.

61 Don Yuçaf Nasí, conocido frecuentemente en la documentación como don Yuçaf el Nasçi, poseía una importante fortuna personal y estuvo vinculado a la Casa de Velasco ya en tiempos del conde don Juan de Velasco, muerto en 1418; con posterioridad, fue arrendador y recaudador mayor de don Pedro Fernández de Velasco y participó activamente en el arrendamiento y recaudación de rentas reales. Entre los años 1427 y 1430 don Yuçaf tuvo arrendada, a través de su criado Juan de Creales, la renta de los diezmos de la mar de Castilla. Véase sobre este particular AMADOR DE LOS RíOS, José, Historia social, política y religiosa de los judíos de España y Portugal. Madrid, 1876, 3 vols. (en concreto, vol. 3, pág. 32, nota 1, y págs. 573-582), y BAER, Fritz, Die Juden im Christlichen Spanien. I/2. Kastilien/Inquisitionakten. Berlín, 1936, doc. núm. 286.

Son muy interesantes las páginas que dedica a don Yuçaf Nasí GARCÍA LUJÁN, José Antonio, en su estudio y colección diplomática titulada Judíos de Castilla (siglos XIV-XV). Documentos del Archivo de los Duques de Frías. Córdoba. Universidad de Córdoba, 1994, págs. 64-97. Asimismo hay algunas referencias a este destacado judío en el estudio de CADIÑANOS BARDECI, Inocencio, «Judería y Morería en Medina de Pomar», en Sefarad, XLV (1985), núm. 2, págs. 237-280. 
reino, se organizó una larga línea defensiva con cuatro sectores, con el fin de hacer frente a las posibles incursiones aragonesas y navarras. Unos apuntes contables de febrero de 1430 hacen referencia a las cantidades que se libraron a don Yuçaf Nasí para que procediera al pago de las tropas destacadas en la frontera con Navarra, que estaban capitaneadas por Pedro Fernández de Velasco, futuro conde de Haro $^{62}$. Asimismo se anota el pago a don Abraham Bienveniste de los maravedíes correspondientes a las 2.000 fanegas de pan que el rey le había mandado vender en la frontera ${ }^{63}$, y se hace constar que don Abraham había prestado al rey la cantidad de 150.000 maravedíes con el fin de pagar las soldadas de las tropas que estaban en la frontera de Aragón ${ }^{64}$. Otros apuntes contables permiten conocer la destacada intervención a lo largo de los años 1429 y 1430 de Abraham Bienveniste y de otros varios judíos en el avituallamiento de los efectivos militares trasladados a la frontera castellana con Navarra y Aragón. Así, sabemos que un vecino de Logroño llamado Fernando Díaz vendió a la corona castellana entre el 1 de marzo de 1429 y el 5 de junio de 1430 un total de 1.876 fanegas de trigo y 1.932 fanegas de cebada, y entre el 17 de diciembre de 1429 y el 3 de septiembre de 1430 otras 3.053 fanegas y 5 cahíces de trigo y 3.077 fanegas y 9 cahíces de cebada, cantidades que le fueron satisfechas con posterioridad por Abraham Bienveniste, Yuçaf Nasí, Yuçaf Bienveniste de Briviesca y Abraham Çabaco, vecino de Herrera de Río Pisuerga ${ }^{65}$. Asimismo, Gonzalo González de Arguiñano, vecino de Calahorra, entre el 20 de febrero y el 8 de julio de 1430 vendió a la corona un total de 1.615 fanegas y 8 cahíces de trigo y 1.723 fanegas y 6 cahíces de cebada, cantidades que le fueron satisfechas posteriormente por Yuçaf Bienveniste y Abraham Çabaco ${ }^{66}$.

Por las mismas fechas, a mediados del mes de marzo de 1430 se produjo el fallecimiento de don Yuçaf Nasí, lo que iba a dar lugar a un largo y enconado pleito con ocasión de las deudas que en el momento de su muerte don Yuçaf tenía con la hacienda regia, así como de las que con él tenía don Pedro Fernández de Velasco. Las cantidades que la hacienda real reclamaba a don Yuçaf correspondían a los impagados por la renta de las albaquías anteriores a 1427 y por otras rentas de los años 1428 a 1430 que dicho judío había tenido arrendadas. Este pleito, en el que tuvo una destacada intervención Abraham Bienveniste, en su condición de tesorero y arrendador mayor de la renta de las albaquías ${ }^{67}$, es analizado detenidamente por José Antonio García Luján en su estudio sobre los judíos castellanos a través de la documentación conservada en el archivo de los Duques

62 AGS, EMR, leg. 1, fols. 103-106.

${ }^{63}$ AGS, EMR, leg. 1, fol. 104.

64 AGS, EMR, leg. 1, fol. 105.

65 AGS, EMR, leg. 1, fol. 203.

66 AGS, EMR, leg. 1, fol. 204.

67 La albaquía es el resto de una cuenta o una renta que queda sin pagar. Las rentas reales de un determinado período de años que quedaban sin percibir eran arrendadas, como una renta más; quien se hacía con la puja debía adelantar la cantidad acordada y, posteriormente, debía esforzarse en cobrar los impagados. 
de Frías ${ }^{68}$, actualmente integrado en la Sección Nobleza del Archivo Histórico Nacional, en su sede de Toledo.

Unos días antes de la muerte de don Yuçaf, el 8 de marzo de 1430 don Pedro Fernández de Velasco suspendió en sus funciones a los dos alcaldes ordinarios de la villa de Medina de Pomar, nombrando en su lugar al alcaide Diego González de Rosales, al que dio poder para librar y ejecutar todo tipo de causas civiles y criminales. El nuevo alcalde inició sus actuaciones el día 23 de marzo, y como primera provisión tuvo que ocuparse de dos asuntos graves que, al parecer, habían tenido lugar en Medina de Pomar, con varios judíos vecinos de esta localidad como protagonistas: uno de ellos se refería a la circuncisión de un cristiano en 1427, y el otro a las relaciones sexuales que, presuntamente, habrían mantenido don Yuçaf Nasí y otros judíos de su entorno con mujeres cristianas, algunas de ellas mujeres casadas y otras mujeres públicas ${ }^{69}$. En la actuación practicada en la primera de las causas, y en la que testificaron varios judíos vecinos de Medina de Pomar, se decía que el cristiano que había sido circuncidado era hijo de un cabaIlero murciano o andaluz que estaba en la frontera de Granada. En primera instancia se habría presentado ante don Abraham Bienveniste en Valladolid, ciudad en la que se encontraba por entonces la corte, manifestando su deseo de convertirse al judaísmo, pero éste no le habría prestado atención, por lo que se dirigió a don Yuçaf Nasí, quien lo habría enviado a Medina de Pomar para que allí le fuera practicada la circuncisión. En su testificación, Yosua (Yehosua) Vallon, vecino de Medina de Pomar, afirmó que había oído decir a Yuçe (Yuçaf) de Laredo, escribano de don Yuçaf Nasí,

«que estando en la corte de nuestro señor el rey en Valladolid, e estando ý don Abraim Bienveniste e el dicho don Yuçaf el Nasçi, que llegara a ellos el dicho ome a les decir cómo su entençión era de ser judío e que lo fiziesen çircuçidar, a lo qual el dicho don Abraim le respondiera quél non sería en tal cosa. E desque el dicho don Yuçaf viera que el don Abraim non quería ser en ello, que enbiara el dicho ome a la dicha villa de Medina con su carta para el dicho don Semuel Avenamias que lo fiziese çirçuçidar, e el dicho don Semuel que lo fiziera ${ }^{70}$."

68 GARCÍA LUJÁN, José Antonio, Judíos de Castilla (siglos XIV-XV). Documentos del Archivo de los Duques de Frías, págs. 75-97.

${ }_{69}$ La información ordenada por don Pedro Fernández de Velasco se practicó en Medina de Pomar ente los días 23 de marzo y 3 de abril de 1430, y se contiene en un documento del archivo de los Duques de Frías: Archivo Histórico Nacional (en adelante AHN), Sección Nobleza, Frías, C.248, D.1), que ha transcrito GARCÍA LUJÁN, José Antonio, Judíos de Castilla (siglos XIV-XV). Documentos del Archivo de los Duques de Frías, doc. 42, págs. 257-273. El documento ha sido también estudiado por PÉREZBUSTAMANTE GONZÁLEZ DE LA VEGA, Rogelio, «Un proceso contra los judíos de Castilla la Vieja. Medina de Pomar, 1430", en Encuentros en Sefarad. Actas del Congreso Internacional sobre los Judíos en la Historia de España (Coords. Manuel Espadas Burgos y Francisco Ruiz Gómez). Ciudad Real. Instituto de Estudios Manchegos, 1987, págs. 45-70.

70 GARCÍA LUJÁN, José Antonio, Judíos de Castilla (siglos XIV-XV). Documentos del Archivo de los Duques de Frías, pág. 261. 
Pese a que es posible que las acusaciones vertidas contra don Yuçaf Nasí fueran falsas, y que todo obedeciera a una artimaña urdida por don Pedro Fernández de Velasco con el fin de quedar libre de las importantes deudas financieras que tenía con el judío, lo que en este momento nos interesa es la noticia que se nos transmite sobre Abraham Bienveniste, y que deja traslucir otro de los rasgos señalados de su personalidad, la prudencia, que fue guía permanente de su actuación pública y privada ${ }^{71}$.

Las importantes deudas que don Yuçaf Nasí tenía con la hacienda regia en el momento de su fallecimiento, con motivo de los impagados por las rentas que había tenido arrendadas en los años anteriores, motivaron una orden regia de embargo de todos los libramientos que se le habían hecho ${ }^{72}$. Del mismo modo, el 2 de abril de 1430 el rey Juan II ordenaba a todos los subarrendadores de don Yuçaf que depositaran sus cuentas, debido a las grandes sumas que éste debía a la corona ${ }^{73}$. Simultáneamente, los hijos de don Yuçaf Nasí (Salamon —Selomoh-, Bienveniste, Mair - Meir - y Dona) entablaron un largo pleito con don Pedro Fernández de Velasco, que se prolongó hasta el año 1440, por las deudas que el conde de Haro tenía con su padre en el momento de su muerte; en este pleito fueron representados por don Mose (Moseh) de Monzón, vecino de Medina de Pomar, quien había sido administrador («facedor») de don Yuçaf Nasí ${ }^{74}$.

En este pleito tuvo una participación muy activa Abraham Bienveniste en su condición de tesorero de la hacienda real, entre cuyas funciones estaba la de transmisor de caudales entre los distintos recaudadores y los beneficiarios de las libranzas emitidas por la Contaduría. A propuesta de los contadores mayores, el rey Juan II encargó a Abraham Bienveniste, tesorero mayor «de las debdas e alcances e albaquías» adeudadas al rey hasta fines del año 1427, que cobrara todas las cantidades que se debían a don Yuçaf Nasí, tanto de los años 1428 a 1430 como de años anteriores, así como que procediera a incautar los bienes que don Yuçaf había dejado al morir y que los pusiera en venta, todo ello con el fin de recuperar los 500.000 maravedíes que se estimaba que don Yuçaf debía a la hacienda regia por las rentas que había tenido arrendadas de los años 1428 a 1430.

El 19 de julio de 1435 tuvo lugar una reunión, en Madrid, entre don Pedro Fernández de Velasco, conde de Haro, quien ostentaba la representación de sus hermanos Fernando y Alonso, como herederos legítimos de sus padres Juan de Velasco y María de Solier, y los tesoreros Alfonso López de Valladolid, Gómez Fernández de Sevilla y Abraham Bienveniste, que eran los delegados regios para

71 GARCÍA LUJÁN, José Antonio, en su estudio Judíos de Castilla (siglos XIV-XV). Documentos del Archivo de los Duques de Frías, págs. 76-77, se refiere de forma detallada a este suceso.

72 AHN, Sección Nobleza, Frías, C.597, D.16. Documento transcrito por GARCíA LUJÁN, José Antonio, Judíos de Castilla (siglos XIV-XV). Documentos del Archivo de los Duques de Frías, doc. núm. 43 , págs. 273-275.

73 BAER, Fritz, Die Juden im Christlichen Spanien. I/2. Kastilien/Inquisitionakten, doc. núm. 286.

74 AHN, Sección Nobleza, Frías, C.248, D.2-4. Transcrito por GARCÍA LUJÁN, José Antonio, Judíos de Castilla (siglos XIV-XV). Documentos del Archivo de los Duques de Frías, doc. núm. 44, págs. 276-279. 
concertar y cobrar las deudas de las albaquías anteriores al año 1427, así como para conocer las deudas que algunos concejos y particulares tenían con don Yuçaf Nasí correspondientes a rentas de los años 1428 a 1430. Pero no se logró alcanzar un acuerdo, ya que don Pedro Fernández de Velasco no sólo negaba que debiera nada de la renta de las albaquías, sino que afirmaba que era don Yuçaf quien debía a sus padres y a él mismo ciertas cantidades por las cuentas de la recaudación de su señorío, de las que había sido tesorero. Ante la falta de acuerdo, las partes nombraron como jueces árbitros a Sancho García de Villalpando y a Gómez Fernández de Sevilla ${ }^{75}$.

Dos años más tarde, el 5 de julio de 1437 se alcanzaba un acuerdo entre las partes en conflicto: los herederos de don Yuçaf Nasí reconocían las cantidades que su padre debía por ciertos «recabdamientos, e rentas, e otros fazimientos" correspondientes a las albaquías anteriores a 1427, cantidades que serían percibidas por los arrendadores de la renta de las albaquías con cargo a los bienes que don Yuçaf había dejado al morir, así como a las cantidades que a él se le debían; y, por otra parte, se especificaban las cantidades que don Juan de Velasco, conde de Haro y padre de Pedro Fernández de Velasco, debía a don Yuçaf. Con el reconocimiento de las deudas por ambas partes, se establecía que el conde de Haro habría de pagar a Abraham Bienveniste 600.000 maravedíes por los derechos que don Yuçaf Nasí y otros arrendadores de rentas reales tenían contra él, y que asimismo debería desembargar todas las casas y bienes inmuebles que poseían don Yuçaf y otros judíos en villas y lugares del señorío de los Velasco, y de las que podría disponer libremente Abraham Bienveniste ${ }^{76}$. Mediante una carta dada en Roa el 28 de mayo de 1438, Pedro Fernández de Velasco se obligaba a pagar a Abraham Bienveniste, tesorero de las deudas, alcances y albaquías que se debían al rey hasta fines del año 1427, los 600.000 maravedíes que adeudaba, según el acuerdo alcanzado ${ }^{77}$. Del mismo modo, el acuerdo de 5 de julio de 1437 fue ratificado el 6 de junio de 1438 por el rey Juan $\mathrm{II}^{78}$, quien ordenó levantar el embargo que pesaba sobre los bienes del conde de Haro y le condonó 200.000 maravedíes, de los 600.000 que debía satisfacer, en reconocimiento por los muchos servicios que le había hecho ${ }^{79}$. Los otros 400.000 maravedíes fueron satisfechos por el conde de Haro con cargo a ciertos libramientos reales que recibió en diversas rentas reales a lo largo de los dos años siguientes, hasta 1440; por fin, el 30 de

\footnotetext{
75 AHN, Sección Nobleza, Frías, C.20, D.5. Transcrito por GARCíA LUJÁN, José Antonio, Judíos de Castilla (siglos XIV-XV). Documentos del Archivo de los Duques de Frías, doc. núm. 47, págs. $284-292$.

${ }^{76}$ AHN, Sección Nobleza, Frías, C.1764, D.22. Transcrito por GARCÍA LUJÁN, José Antonio, Judíos de Castilla (siglos XIV-XV). Documentos del Archivo de los Duques de Frías, doc. núm. 51, págs. 300-315.

77 AHN, Sección Nobleza, Frías, C.597, D.44. Transcrito por GARCíA LUJÁN, José Antonio, Judíos de Castilla (siglos XIV-XV). Documentos del Archivo de los Duques de Frías, doc. núm. 52, págs. $315-320$.

78 AHN, Sección Nobleza, Frías, C.597, D.36. Transcrito parcialmente por GARCíA LUJÁN, José Antonio, Judíos de Castilla (siglos XIV-XV). Documentos del Archivo de los Duques de Frías, doc. núm. 53, págs. 320-323. El documento tiene el interés añadido de que contiene la rúbrica de Abraham Bienveniste.

79 AHN, Sección Nobleza, Frías, C.597, D.37. Transcrito por GARCÍA LUJÁN, José Antonio, Judíos de Castilla (siglos XIV-XV). Documentos del Archivo de los Duques de Frías, doc. núm. 54, págs. 323-326.
} 
junio de 1440 Abraham Bienveniste le dio la carta de finiquito ${ }^{80}$. La resolución del pleito fue, por tanto, muy favorable para los intereses del conde de Haro, quien no hubo de desembolsar ninguna cantidad de dinero en efectivo.

Pero una vez analizada la intervención de Abraham Bienveniste como tesorero de las albaquías en el pleito que enfrentó a don Pedro Fernández de Velasco con los herederos de don Yuçaf Nasí, es necesario centrar ahora la atención en su papel como arrendador de rentas reales. Pese a que, como ya advirtió Angus MacKay ${ }^{81}$, probablemente haya que moderar el papel que, con frecuencia, se ha asignado a Abraham Bienveniste en los arrendamientos de la «masa» (es decir de la totalidad de las rentas tomadas en su conjunto) de las rentas reales de los años treinta y cuarenta del siglo XV, no es menos cierto que don Abraham intervino de forma activa, junto a otros importantes financieros, en buena medida judeoconversos, en el arrendamiento de la «masa» de las tercias y alcabalas del reino a lo largo de los dos decenios señalados.

La primera intervención documentada de Abraham Bienveniste en el arrendamiento de rentas reales se produce con ocasión del arrendamiento de la «masa» de las alcabalas y tercias del reino de Castilla correspondiente a los años 1432 a 1434. Junto a Abraham Bienveniste figuran también como arrendadores y recaudadores de la «masa», todos y cada uno de ellos con una catorceava parte del total, don Yuçaf Bienveniste de Briviesca, Diego Hernández de León, Alvar González de León, Juan Martínez de Burgos, Juan Ramírez de Toledo, Alonso López de VaIladolid, Pedro Franco, Luis González de Guadalajara, Juan González de la Plazuela, Pedro Fernández de Alcaraz, Fernán García de Astorga, Alonso López de Córdoba, Gómez Fernández de Sevilla y Juan Rodríguez de Sevilla. El arrendamiento de la «masa» de 1432-1434 fue acordado en Zamora el día 12 de diciembre de 1431, ante el rey Juan II (albalá otorgado el día 30 de diciembre de 1431) ${ }^{82}$.

Asimismo, Abraham Bienveniste es uno de los siete arrendadores mayores de la «masa» de las alcabalas y tercias de los años 1435 a 1437. Junto a Abraham Bienveniste figuran también como arrendadores y recaudadores mayores de la «masa» don Yuçaf Bienveniste de Briviesca, los tesoreros Juan Martínez de Burgos y Pedro Franco de Toledo, Luis González de Toledo, Pedro Fernández de Alcaraz y Gómez Fernández de Sevilla ${ }^{83}$. A lo largo de los últimos días del mes de noviembre y los primeros del de diciembre de 1434, los siete arrendadores mayores de la «masa»

80 AHN, Nobleza, Frías, C.597, D.44. Transcrito por GARCÍA LUJÁN, José Antonio, Judíos de Castilla (siglos XIV-XV). Documentos del Archivo de los Duques de Frías, doc. núm. 55, págs. 326-328. El documento contiene un breve texto autógrafo de Abraham Bienveniste («Es la quantía desta carta seisçientas mille maravedís. Abrahen»), con su rúbrica en hebreo.

81 MACKAY, Angus, «Popular Movements and Pogroms in fifteenth century Castile», págs. 41-44.

82 AGS, Cámara de Castilla, Diversos, leg. 4, doc. 60 - AGS, EMR, leg. 1, fols. 265-267. ORTEGO RICO, Pablo, Hacienda, poder real y sociedad en Toledo y su Reino (siglo XV-principios del XVI), vol. II, págs. 859-860, 865 y 866 , tabla 186 .

${ }^{83}$ AGS, EMR, leg. 1, fols. 244-250 y 262. ORTEGO RICO, Pablo, Hacienda, poder real y sociedad en Toledo y su Reino (siglo XV-principios del XVI), vol. II, págs. 537 y 866, tabla 186. 
de las alcabalas y tercias del trienio 1435-1437 se encontraban residiendo en Madrid, ciudad en la que por entonces se encontraba la corte real. Durante los primeros días del mes de diciembre de 1434 se celebraron varias reuniones de los siete «arrendadores mayores» en la posada madrileña en la que se alojaba Abraham Bienveniste, con el fin de pujar para hacerse con el arrendamiento y recaudación de los partidos fiscales que cada cual consideraba más idóneos para sus intereses particulares; con motivo de estas licitaciones surgieron ciertas disputas internas, a las que se puso fin el día 9 de diciembre anulándose todo el procedimiento realizado hasta ese momento ${ }^{84}$. La mayor parte de las reuniones celebradas con ocasión de estas licitaciones tuvieron por escenario la posada de Abraham Bienveniste, lo que constituye una prueba inequívoca de que se trataba de la persona más influyente del grupo. Los testigos de la reunión del día 9 de diciembre, en la que se acordó la anulación de todo el procedimiento de licitaciones realizado hasta entonces, fueron los escribanos reales Ruy González de Çifueros, Pedro García de Villadiego, y Alfón de Santa Clara, escudero de Abraham Bienveniste ${ }^{85}$.

En 1435 Abraham Bienveniste era uno de los arrendadores mayores de la «masa» de las «monedas», junto con el tesorero Pedro Franco de Toledo, Juan Martínez de Burgos y Pedro González, quienes el 29 de abril de 1435 suscribían en Madrid el repartimiento por partidos fiscales de los 28.480 .678 maravedíes que sumaba el total de esta renta en virtud de la postura presentada ${ }^{86}$.

A través de datos indirectos, todo permite suponer que Abraham Bienveniste y Juan Ramírez de Toledo ${ }^{87}$, quizá junto con otros financieros desconocidos, arrendaron la «masa» de las tercias y alcabalas del bienio 1438-1439, aunque, al no conservarse la documentación correspondiente, no es posible conocer su participación efectiva en dicho arrendamiento ${ }^{88}$. En el Libro de recepta de 1439 Abraham Bienveniste figura como arrendador y recaudador mayor de la renta de las alcabalas y tercias de las merindades de Burgos y Allende Ebro ${ }^{89}$, y como recau-

${ }^{84}$ AGS, EMR, leg. 1, fols. 244-250. ORTEGO RICO, Pablo, Hacienda, poder real y sociedad en Toledo y su Reino (siglo XV-principios del XVI), vol. II, págs. 863-864.

${ }_{85}$ AGS, EMR, leg. 1, fol. 249 v. ORTEGO RICO, Pablo, Hacienda, poder real y sociedad en Toledo y su Reino (siglo XV-principios del XVI), vol. II, pág. 864, nota 3020.

${ }^{86}$ AGS, EMR, leg. 1, fol. 239. ORTEGO RICO, Pablo, Hacienda, poder real y sociedad en Toledo y su Reino (siglo XV-principios del XVI), vol. I, pág. 537, y vol. II, pág. 881.

${ }_{87}$ Juan Ramírez de Toledo era vecino de Toledo y pertenecía a una de las familias judeoconversas que mayor protagonismo político tuvieron a lo largo del reinado de Juan II. Mantuvo unas intensas relaciones financieras con Álvaro de Luna y, al menos desde 1431, desempeñó el cargo de tesorero real. Tuvo una intervención muy activa en el arrendamiento de la «masa» de las rentas ordinarias del reino, principalmente tercias y alcabalas, a lo largo de los años treinta y cuarenta del siglo XV, normalmente en compañía del también tesorero Abraham Bienveniste.

${ }^{8}$ AGS, EMR, leg. 1, fols. 161r-162r. ORTEGO RICO, Pablo, Hacienda, poder real y sociedad en Toledo y su Reino (siglo XV-principios del XVI), vol. II, pág. 866.

89 Los fiadores de estas operaciones financieras fueron Juan de Luna, Gonzalo Díaz de Cuevas, don Yuça Bienveniste de Briviesca, don Yuça Barchilón, Gonzalo Rodríguez del Río, Juan López de Asayuel y don Salamón de la Cavallería, vecino de Soria (AGS, EMR, leg. 1, Libro de recebta de 1439, fols. 132, 140 y $161-162$, y leg. 2 , fols. 40r-42v). 
dador mayor de las tercias de los Obispados de Osma y Segovia ${ }^{90}$. También en 1439 Abraham Bienveniste y Juan Ramírez de Toledo hubieron de hacer frente a dos quiebras de 5.000 y 50.000 maravedíes en los partidos de Sigüenza y Atienza, por cuanto no habían dado fianzas por las rentas de las alcabalas y tercias; al no hacerse cargo finalmente de su recaudación, en la subasta subsiguiente quedaron rematadas en cantidades inferiores a las pujadas inicialmente, por lo que los nuevos recaudadores adquirían el compromiso de percibir de los arrendadores de la «masa» la diferencia existente, a la que se calificaba como quiebra ${ }^{91}$. No era infrecuente que esto sucediera, quizá debido al deseo de evitar las molestias que conllevaba constituir las fianzas; así, en 1439 Abraham Bienveniste y Juan Ramírez de Toledo tuvieron que hacer frente a una quiebra de 20.000 maravedíes en la renta de las tercias del arcedianazgo de Madrid, de la que inicialmente figuraban como arrendadores pero que luego quedó en manos de Alonso de Herrera, debido a que tampoco habían satisfecho fianzas y la cantidad en que se subastó en segunda instancia fue inferior en $\mathbf{2 0 . 0 0 0}$ maravedíes a la que anteriormente ellos habían ofrecido ${ }^{92}$.

En compañía de Juan Ramírez de Toledo, Abraham Bienveniste se hizo con la totalidad de la «masa» de las alcabalas y tercias del reino correspondiente a los años 1440 a 1443 , si bien con posterioridad ambos arrendadores hicieron traspaso a otros financieros de la mayor parte de las fracciones de la «masa», de forma que Ramírez de Toledo sólo se encargó de la gestión efectiva de 6/35 partes y Abraham Bienveniste quizá tuviera una participación aún menor ${ }^{93}$. Éste era el procedimiento habitual para la recaudación de las rentas arrendadas en «masa», de forma que, una vez ganada la puja, se procedía a la distribución por partidos fiscales de la cantidad total licitada; en esta ocasión, los traspasos se hicieron a los siguientes financieros: Luis González de Toledo (1/15), Gómez Fernández de Sevilla (1/15), el licenciado Pedro Martínez de Toledo (1/15), el tesorero Fernán García de Astorga (1/15 + 3/35), Alfón Díaz de Medina (1/15), Fernán Gómez de Córdoba (1/15), Fernán González de Orihuela (1/15), don Yuçaf Bienveniste (1/15), don Abraham Çabaco (1/15) y Ruy González de Ávila (1/7).

Como garantía de cumplimiento de la puja realizada, los arrendadores mayores de la «masa» debían presentar fianzas ante los contadores mayores del reino, fianza que en esta ocasión ascendió a la suma de 4.000.000 de maravedíes. A su vez, los arrendadores de los distintos partidos o circunscripciones fiscales debían

\footnotetext{
90 AGS, EMR, leg. 1, Libro de recebta de 1439, fols. 146-147, y leg. 2, fols. 40r-42v.

91 AGS, EMR, leg. 1, fols. 160r-162r. ORTEGO RICO, Pablo, Hacienda, poder real y sociedad en Toledo y su Reino (siglo XV-principios del XVI), vol. II, pág. 879.

92 AGS, EMR, leg. 1, fols. 167r-168r. ORTEGO RICO, Pablo, Hacienda, poder real y sociedad en Toledo y su Reino (siglo XV-principios del XVI), vol. II, pág. 879.

93 Así, Abraham Bienveniste y Juan Ramírez de Toledo gestionaron de forma directa la recaudación de las alcabalas y tercias del partido de realengo y abadengo de la merindad de Santo Domingo de Silos, del Obispado de Ávila y del partido de Atienza. AGS, EMR, leg. 2, fols. 37v-40r y 126-226. ORTEGO RICO, Pablo, Hacienda, poder real y sociedad en Toledo y su Reino (siglo XV-principios del XVI), vol. II, pág. 879 .
} 
presentar también fianzas, por valor de un tercio del precio de la renta. En la amplia nómina de fiadores que presentó Abraham Bienveniste por este arrendamiento de la «masa» aparecen cuatro cristianos y once judíos; estos fiadores judíos son los siguientes: don Yuçaf Abenpex, vecino de la localidad vallisoletana de Villafrechós; Jacob (Yaaqob) Gaón, vecino de Vitoria; Yuçaf Barchilón, vecino de Soria; Salamón (Selomoh) de la Caballería, vecino de Soria; Mayr (Meir) el Levi, hijo de don Meir el Levi, vecino de Soria; don Abraham Bienveniste, hijo de don Salamón (Selomoh) Bienveniste, vecino de Almazán; don Abraham Bienveniste, hijo de don Profet, vecino de Soria; Jacob (Yaaqob) de Cuéllar; Mayr (Meir) el Levi, hijo de don Abraham el Levi, vecino de Soria; don Yuçaf Bienveniste, hijo de don Abraham Bienveniste; y don Salamón (Selomoh) Bienveniste, hijo de don Abraham Bienveniste ${ }^{94}$.

Junto al elevado número de fiadores judíos, señal evidente del importantísimo papel que en la constitución de las compañías para la recaudación de rentas reales tenía el elemento socio-religioso, llama la atención la preponderancia en esta nómina de judíos vecinos de Soria, lo que, con toda probabilidad, guarda relación con los orígenes sorianos de Abraham Bienveniste. Asimismo es notorio el número de judíos apellidados Bienveniste, probablemente familiares en distinto grado de Abraham Bienveniste (entre ellos sus hijos Yuçaf y Selomoh), lo que es una señal indudable del frecuente recurso a familiares, amigos y convecinos para dar cumplimiento a las distintas operaciones financieras relativas al arrendamiento y recaudación de rentas que debían ser llevadas a cabo por quienes pujaban a las mismas. En cualquier caso, las nóminas de fiadores son siempre de gran interés ya que, además de actuar como soporte financiero de los arrendadores mayores de la «masa», estos fiadores solían tener intereses particulares en el arrendamiento de las rentas de ciertos partidos fiscales, para lo que formaban compañías propias o se integraban en algunas ya constituidas.

El escrito de postura que presentaron el 31 de enero de 1440, ante el rey Juan II, Abraham Bienveniste y Juan Ramírez de Toledo, nos informa con detalle acerca de las condiciones que fueron fijadas por los contadores mayores del reino para el arrendamiento de la «masa» de las tercias y alcabalas de los años 1440 a 1443, y que tenían como finalidad principal garantizar un estricto control de la recaudación de las rentas del reino. Como es habitual en este tipo de escritos, fue regulada minuciosamente la forma de efectuar los pagos y las garantías que permitirían llevar a cabo con éxito la recaudación ${ }^{95}$. Los arrendadores mayores recibían, a su vez, garantía de que no se realizaría ninguna puja durante el período de cuatro años de su arrendamiento, ni sobre el total de las rentas de la «masa»

\footnotetext{
${ }_{94}$ AGS, EMR, leg. 2, fols. 22-232 y 532, Libro de recepta de 1440-1443. Pablo ORTEGO RICO, Hacienda, poder real y sociedad en Toledo y su Reino (siglo XV-principios del XVI), vol. II, pág. 867.

${ }_{95}$ AGS, EMR, leg. 2, fols. 22r-26v. ORTEGO RICO, Pablo, Hacienda, poder real y sociedad en Toledo y su Reino (siglo XV-principios del XVI), vol. II, págs. 860-861.
} 
ni sobre el precio que quedara fijado para cada partido fiscal después de realizado el repartimiento.

\section{A MODO DE CONCLUSIÓN}

De cuanto hasta aquí se ha dicho, es posible concluir que los orígenes de Abraham Bienveniste se encuentran en Soria, ciudad con la que mantuvo, con toda seguridad, estrechos vínculos afectivos y profesionales ${ }^{96}$, pese a que, en su condición de «judío cortesano», se viera obligado a seguir los continuos traslados de una corte itinerante ${ }^{97}$.

Su llegada a la corte de Juan II se produjo de la mano de quien fue su valedor, Juan Hurtado de Mendoza, mayordomo mayor del rey, para quien desempeñó, con toda probabilidad, funciones de mayordomía y administración de bienes. Al menos desde 1420 estuvo ligado a la figura del condestable Álvaro de Luna, conociendo los vaivenes de la convulsa historia política castellana de la primera mitad del siglo XV. De este modo, la tarea que le fue confiada en la corte por Juan Hurtado de Mendoza y Álvaro de Luna sirvió, entre otros, de argumento justificativo del golpe de Tordesillas de julio de 1420; en un momento en el que eran muchos los que consideraban que el judaísmo castellano estaba próximo a su fin, debió verse como un hecho escandaloso que un judío alcanzara nuevamente una destacada posición en la corte, contraviniendo, además, las disposiciones contenidas en la Pragmática de la regente Catalina de Lancáster de 1412. Algo que fue aprovechado por el infante don Enrique para su utilización demagógica y partidista frente al valido real Álvaro de Luna.

Desde su privilegiada posición en la corte, Abraham Bienveniste se preocupó por mejorar las condiciones en las que se desenvolvía la vida de la comunidad judía. Su nombramiento como Rab Mayor de los judíos de Castilla, el 26 de noviembre de 1431, obedeció, sin duda alguna, a una decidida voluntad política de Álvaro de Luna de procurar la reconstrucción del judaísmo castellano, considerablemente mermado tras las violentas persecuciones de 1391 y las disposiciones legales aprobadas en los primeros años del siglo XV, en particular la Pragmática de 1412, acontecimientos éstos que fueron causa de una conversión masiva de judíos al cristianismo. En mi opinión, no es casualidad que tan sólo unos meses después de su nombramiento como Rab Mayor se celebrara la asamblea de notables judíos, presidida por él mismo, en la que se aprobaron las Taqqanot de Valladolid de 1432, cuyo objetivo principal consistía en propiciar un restablecimiento de las comunidades judías. Nuevamente hay que ver tras la asamblea de Valladolid la sombra del condes-

96 Ya tuvimos ocasión de comprobar cómo entre los fiadores que presentó para el arrendamiento de la «masa» de las alcabalas y tercias del reino de Castilla correspondiente al cuatrienio de 1440-1443 figuran diversos judíos sorianos.

97 Para conocer los lugares de residencia de la corte castellana a lo largo del reinado de Juan II puede acudirse al excelente estudio, ya citado anteriormente, de CAÑAS GÁLVEZ, Francisco de Paula, El itinerario de la corte de Juan II de Castilla (1418-1454). Madrid. Editorial Sílex, 2007. 
table Álvaro de Luna, quien estaba convencido del importante papel que los judíos estaban llamados a tener en su proyecto de reorganización de la hacienda regia, lo que consideraba un pilar fundamental para una monarquía sólida. En este sentido, como persona de confianza que era de Álvaro de Luna, Abraham Bienveniste contribuyó a facilitarle el control del sistema hacendístico de la corona, un objetivo para el que fueron también figuras absolutamente fundamentales los contadores mayores Alonso Álvarez de Toledo y Fernán López de Saldaña, ambos judeoconversos ${ }^{98}$.

Por otra parte, independientemente de que el papel desempeñado por Abraham Bienveniste en el arrendamiento de rentas reales fuera de mayor o menor relevancia - ya he hecho referencia con anterioridad a que, en opinión de Angus MacKay, este papel se ha exagerado un tanto-, es evidente que formaba parte de un selecto grupo financiero que disponía del suficiente potencial económico como para pujar y hacerse con el arrendamiento de la «masa», así como de la imprescindible capacidad de relacionarse económica, social y políticamente en distintos entornos locales o comarcales para, una vez ganada la puja, poder organizar el subarrendamiento por partidos o circunscripciones fiscales. Porque quienes se hacían con el arrendamiento de la «masa» no sólo tenían que disponer de los capitales necesarios para anticipar las cantidades correspondientes a la hacienda regia, sino que, posteriormente, debían ser capaces de organizar la recaudación de las rentas. Buena muestra de la pujanza económica de Abraham Bienveniste es que conocemos los nombres de algunas personas que trabajaban bajo sus órdenes, y que, además, eran cristianos, quizá cristianos nuevos: Alfón de Santa Clara, a quien se cita como escudero de Abraham Bienveniste ${ }^{99}$, y Pedro de Baeza, de quien se dice que era su criado ${ }^{100}$.

Parece fuera de toda duda que el número de judíos dedicados a la gestión de los recursos fiscales del reino de Castilla había disminuido de forma considerable tras las persecuciones de 1391 y las disposiciones legales que fueron aprobadas durante los primeros años del siglo XV, en particular la Pragmática de doña Catalina de 1412; pese a todo, los judíos continuaron teniendo un cierto protagonismo en estas tareas. No hay que perder de vista que la Pragmática de 1412 quedó en sus-

\footnotetext{
98 Acerca de estos dos personajes, véase CAÑAS GÁLVEZ, Francisco de Paula, Burocracia y canciIlería en la corte de Juan II de Castilla (1406-1454). Estudio institucional y prosopográfico. Salamanca. Universidad de Salamanca, 2012.

99 AGS, EMR, leg. 1, fol. 249v. ORTEGO RICO, Pablo, Hacienda, poder real y sociedad en Toledo y su Reino (siglo XV-principios del XVI), vol. II, pág. 864, nota 3020.

100 El 22 de octubre de 1437 Pedro de Baeza, criado del tesorero don Abraham Bienveniste, otorgó una escritura en Sevilla declarando que la heredad de Bercel, donadío situado cerca de las Cabezas de San Juan, en el término de la ciudad de Sevilla, pertenecía a don Pedro Ponce de León, conde de Medellín y señor de Marchena, pues la había comprado en su nombre y con su dinero en el concurso que se hizo de los bienes de Juan Gutiérrez de Camargo y de su mujer Leonor de Barba, con el fin de hacer pago a los arrendadores de ciertas deudas que tenían por el arrendamiento de varias rentas de aquella ciudad, todo ello según avenencia de Juan Gutiérrez con los avenidores de las deudas, alcances y albaquías que eran debidas al rey por los años pasados hasta fines de 1427 (AHN, Sección Nobleza, Osuna, c.187, D.20). Agradezco a D. Efrén de la Peña las facilidades que me ha dado para la consulta de diversos documentos de la Sección Nobleza del Archivo Histórico Nacional citados en este estudio.
} 
penso en 1418, cuando iba a iniciarse el gobierno personal de Juan II, al alcanzar la mayoría de edad, y que a partir de este momento tuvo lugar un proceso de reconstrucción parcial de las comunidades judías castellanas. Pero la presencia judía en el arrendamiento de la «masa» era ya bastante limitada en los años treinta y cuarenta del siglo XV, de forma que la participación de Abraham Bienveniste, Yuçaf Bienveniste de Briviesca y Abraham Çabaco no superaba el $28 \%$ del total de la renta entre 1435 y 1437, y entre 1444 y 1450 no hay constancia de la intervención de ningún judío en el arrendamiento de la «masa». Es posible que la desaparición de los judíos en el arrendamiento de la «masa» a partir del año 1444 guarde alguna relación con la promulgación, el 6 de abril de 1443, tras el retorno de Álvaro de Luna a la corte después del destierro que sufrió en 1442, de una pragmática en la que se prohibía a los judíos ejercer como arrendadores o recaudadores de rentas ${ }^{101}$. En el texto de la pragmática se explica que esta prohibición obedecía al propósito de desautorizar una de las razones que más se argumentaban por parte de determinados sectores opuestos a Álvaro de Luna sobre la supuesta influencia política y, sobre todo, económica, que algunos judíos poderosos tenían sobre el valido real, algo que resultaba demasiado evidente por el apoyo financiero que le prestaban ${ }^{102}$. El relevo en la administración de la «masa» sería tomado por financieros judeoconversos, quienes desde entonces tuvieron, y así fue a lo largo de la segunda mitad del siglo XV y los primeros decenios del XVI, el control efectivo de buena parte de las rentas reales, ya que al arrendar la «masa» controlaban también el arrendamiento de las rentas por partidos o circunscripciones fiscales.

Desde muy pronto Abraham Bienveniste asoció a su hijo Yuçaf Bienveniste a sus gestiones hacendísticas, lo que permitió a éste llegar a ser uno de los más importantes financieros castellanos en los años cincuenta y sesenta del siglo XV. Si bien José Antonio García Luján identifica a este Yuçaf Bienveniste con Yuçaf Bienveniste de Briviesca, vecino de esta localidad burgalesa ${ }^{103}$ y que aparece ya como arrendador de la «masa» de las tercias y alcabalas del reino de Castilla desde principios de los años treinta ${ }^{104}$, nos inclinamos a pensar que se trata de dos personas distintas. Yuçaf Bienveniste aparece citado como hijo de Abraham Bienveniste en un documento dado en Valladolid el 22 de diciembre de 1452, por el que arrendaba de don Álvaro de Luna las rentas de los pechos, derechos, alcabalas, tercias y monedas de ciertas villas pertenecientes al maestrazgo de Santia-

101 AMADOR DE LOS RÍOS, José, Historia social, política y religiosa de los judíos de España y Portugal. Madrid, 1876, 3 vols., vol. III, pág. 585.

102 Véase al respecto MONSALVO ANTÓN, José María, Teoría y evolución de un conflicto social. El antisemitismo en la Corona de Castilla en la Baja Edad Media. Madrid. Siglo XXI, 1985, págs. 292-294.

103 GARCÍA LUJÁN, José Antonio, Judíos de Castilla (siglos XIV-XV). Documentos del Archivo de los Duques de Frías, págs. 100-103.

104 Yuçaf Bienveniste de Briviesca figura también como recaudador mayor de las alcabalas de la merindad de Castilla Vieja y de las tercias de Valpuesta de los años 1441 a 1444 (AGS, EMR, leg. 2, fol. 136) y del primer pedido y quince monedas de la merindad de Castilla Vieja del año 1442 (AGS, EMR, leg. 2, fol. 408). En diversas ocasiones se cita como hijo suyo a Mayr (Meir) Bienveniste, vecino de Briviesca o de Peñaranda; así, padre e hijo figuran entre los fiadores del arrendamiento de la renta de las albaquías de los años anteriores a 1452 (AGS, EMR, leg. 7, fols. 60-61). 
go, correspondientes a los años 1453 y 1454, por un total de 1.278 .118 maravedíes y 2 cornados anuales. Este documento está inserto en otro otorgado en Dueñas el 22 de abril de 1453, por el que Yuçaf Bienveniste se obligaba a recaudar para el rey Juan II estas rentas, que habían sido embargadas por la corona al caer en desgracia el valido real ${ }^{105}$. Pese a que en el documento no se incluya ninguna de las fórmulas habituales de encomendación del alma de Abraham Bienveniste, o indicativa de su condición de finado, su fallecimiento había tenido lugar a fines del año 1449 o en los primeros meses de 1450.

En los arrendamientos de rentas reales de los años cincuenta y sesenta del siglo XV aparece citado con frecuencia Yuçaf Bienveniste como vecino de Segovia ${ }^{106}$, y se cita asimismo a un don Salomón (Selomoh) Bienveniste, hijo de don Abraham y hermano de don Yuçaf ${ }^{107}$, quien se trataba, con toda probabilidad, de otro hijo de Abraham Bienveniste. Un tercer hijo del Rabí Mayor, llamado don Huda (Yehudah) Bienveniste, aparece citado como vecino de Soria y hermano de don Yuçaf Bienveniste en documentación de comienzos de los años sesenta del siglo $X V^{108}$.

A su vez, Yuçaf Bienveniste asoció también muy pronto a su gestión hacendística a sus hijos Vidal y Abraham, vecinos de Guadalajara, quienes llegaron a ser dos de los financieros más importantes de la Castilla de los años finales del reinado de Enrique IV y de la primera parte del de los Reyes Católicos ${ }^{109}$. En definitiva, la trayectoria de la familia Bienveniste en su relación con la Hacienda real constituye un magnífico ejemplo de adaptación a las difíciles y cambiantes circunstancias que marcaron la política castellana en el siglo XV, lo que posibilitó su permanencia en los puestos más elevados de la estructura financiera de la corona castellana durante al menos tres generaciones.

105 GARCÍA LUJÁN, José Antonio, Judíos de Castilla (siglos XIV-XV). Documentos del Archivo de los Duques de Frías, págs. 102-103 y doc. núm. 61, págs. 341-345.

106 Por ejemplo, en el arrendamiento que hizo de las alcabalas de la merindad de Allende Ebro de los años 1454 a 1456 (AGS, EMR, leg. 6, fol. 76), o en el recaudamiento que hizo don Vidal Bienveniste en nombre de su padre don Yuça (Yuçaf), hijo de don Abraham Bienveniste y vecino de Segovia, de las alcabalas y tercias del obispado de Guadalajara correspondientes al año 1462 (AGS, EMR, leg. 10, fol. 41).

107 Entre los arrendadores de la «masa» de las alcabalas y tercias de 1455 a 1458 aparecen Juan Ramírez de Lucena, Alfonso González de Ferrera, Diego Álvarez de Córdoba. Alfonso Díaz de Villarreal, maestre Alfonso de Roa, don Salomón (Selomoh) Bienveniste, su hermano Yuça (Yuçaf) Bienveniste y don Mosé (Moseh) Abenmenir (AGS, EMR, leg. 7).

108 AGS, EMR, leg. 14, fol. 47. ORTEGO RICO, Pablo, Hacienda, poder real y sociedad en Toledo y su Reino (siglo XV-principios del XVI), vol. II, pág. 1123.

109 Abraham y Vidal Bienveniste son citados como fiadores de su padre, Yuçaf Bienveniste, en el arrendamiento que hizo de las $3 / 4$ partes de las alcabalas y tercias del obispado de Córdoba para los años 1463-1465; en este mismo documento se hace constar también la obligación adquirida como fiador por don Huda (Yehudah) Bienveniste, vecino de Soria y hermano de don Yuçaf (AGS, EMR, leg. 14, fol. 47). ORTEGO RICO, Pablo, Hacienda, poder real y sociedad en Toledo y su Reino (siglo XV-principios del XVI), vol. II, pág. 1123. 
